\title{
Sustainable Development of Food Safety
}

- new bearings in the Nordic countries 



\section{Sustainable Development of Food Safety}

- new bearings in the Nordic countries

by

Bente Fabech

Franklín Georgsson

Jørn Gry

Sigurður Örn Hansson

Lulu CH Krüger

Brynjulf Melhuus

Jan Movitz

Harriet Wallin.

TemaNord 2004:536 


\section{Sustainable Development of Food Safety - new bearings in the Nordic countries}

TemaNord 2004:536

(C) Nordic Council of Ministers, Copenhagen 2004

ISBN 92-893-1033-2

ISSN 0908-6692

Print: Ekspressen Tryk \& Kopicenter

Cover: Kjell Olsson - NMR/PUB

Copies: 600

Printed on paper approved by the Nordic Environmental Labelling.

This publication may be purchased from any of the sales agents listed on the last page.

Nordic Council of Ministers

Store Strandstræde 18

DK-1255 Copenhagen K

Phone (+45) 33960200

Fax (+45) 33960202
Nordic Council

Store Strandstræde 18

DK-1255 Copenhagen K

Phone (+45) 33960400

Fax $\quad(+45) 33111870$

www.norden.org

\section{The Nordic Food Policy Co-operation}

The Nordic Committee of Senior Officials for Food Issues is concerned with basic Food Policy issues relating to food and nutrition, food toxicology and food microbiology, risk evaluation, food control and food legislation. The co-operation aims at protection of the health of the consumer, common utilisation of professional and administrative resources and at Nordic and international developments in this field.

\section{The Nordic Council of Ministers}

was established in 1971. It submits proposals on co-operation between the governments of the five Nordic countries to the Nordic Council, implements the Council's recommendations and reports on results, while directing the work carried out in the targeted areas. The Prime Ministers of the five Nordic countries assume overall responsibility for the co-operation measures, which are co-ordinated by the ministers for co-operation and the Nordic Co-operation committee. The composition of the Council of Ministers varies, depending on the nature of the issue to be treated.

\section{The Nordic Council}

was formed in 1952 to promote co-operation between the parliaments and governments of Denmark, Iceland, Norway and Sweden. Finland joined in 1955. At the sessions held by the Council, representatives from the Faroe Islands and Greenland form part of the Danish delegation, while Åland is represented on the Finnish delegation. The Council consists of 87 elected members - all of whom are members of parliament. The Nordic Council takes initiatives, acts in a consultative capacity and monitors co-operation measures. The Council operates via its institutions: the Plenary Assembly, the Presidium and standing committees. 


\section{Content}

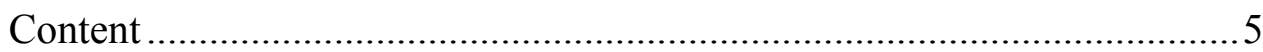

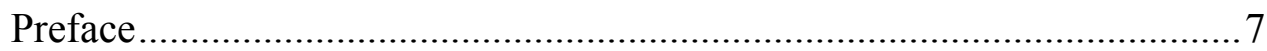

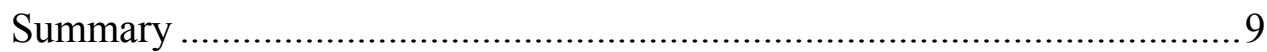

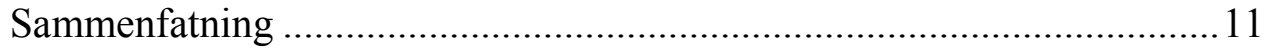

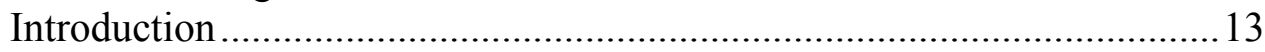

1 Food safety and sustainable development......................................... 15

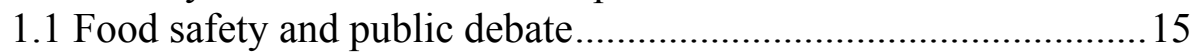

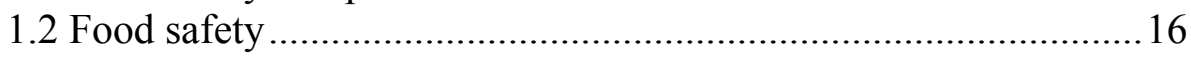

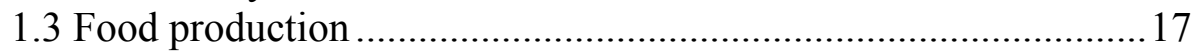

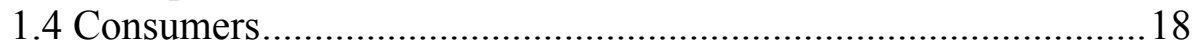

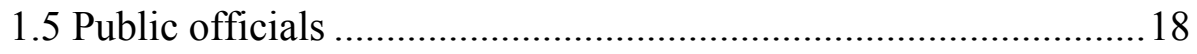

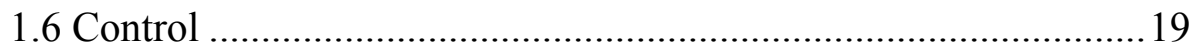

1.7 National and international regulations ......................................... 19

1.8 Activities and initiatives to date.................................................20

1.9 Long-term measures for sustainable development........................22

2 Goals and indicators for each goal...............................................25

2.1 Targets and measures 2005-2008 - a general introduction..........25

2.2 Indicators - which, when and how.............................................25

2.3 Comparison of data ................................................................... 26

2.4 Surveillance data versus control data..........................................26

2.5 The goals and proposals for present and future indicators............27

Goal: Improve efforts for animal health and welfare in relation to food

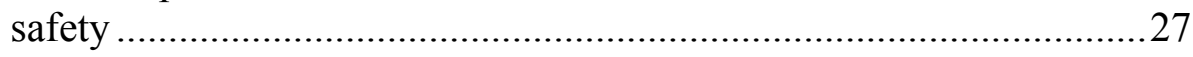

Goal: Strengthen efforts against zoonoses and pathogenic microorganisms

Goal: Strengthen safe food handling and food production in industry and with consumers

Goal: Restrict the occurrence of chemical contaminants, and ensure that only well-examined production aids, food additives, and flavours are used

Goal: Increase knowledge about and reduce the risk of natural inherent toxicants 39

Goal: Strengthen efforts for prevention, and improve knowledge on dietrelated hypersensitivity reactions. 40 
Goal: Strengthen knowledge about the relationship between diet, nutrition,

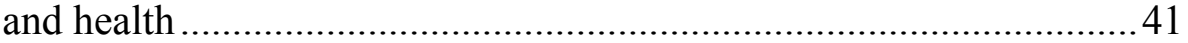

Goal: Strengthen traceability and in-house control ..........................45

Goal: Strengthen scientific knowledge of food safety ...................... 47

Goal: Strengthen consumer knowledge ........................................48

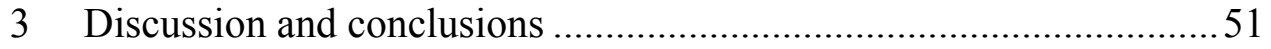




\section{Preface}

The Nordic Council of Ministers developed the first, joint strategy on sustainable development in various areas and published it in 2001: "Sustainable development - new bearings in the Nordic countries" - Denmark, Finland, Iceland, Norway and Sweden. This strategy included sustainable development of food safety and had formulated 10 goals to be dealt with during the years up to 2005 , together with sustainable development in other areas.

Food safety and sustainable development have high priority in the Nordic countries. By this the Nordic countries want to prioritise both protection of the consumers in this generation and future generations and ensuring a sustainable development in the safety of food. Food safety is furthermore of importance for export and import of food from and to the Nordic countries. The Nordic countries have a considerable export of foodstuffs to countries all over the world and require safe and sustainable food production not only on the home market, but also for high standard exports.

All the goals formulated in 2001, for 2001-2004, have been dealt with, some have been completed; others not jet - mainly because these are goals for ongoing activities like participation in international work in the food safety area. As an ongoing process, the goals have to reflect the international request for food safety and for sustainable developments. The goals from 2001 have been revised in accordance with developments in knowledge etc. and new goals are set up for the next period, 2005-2008. The goals for the future are also part of a compiled revised strategy covering environment, fishery, agriculture etc. (Nordic Council of Ministers, in proces, May 2004).

The Rio-conference on sustainable development in 1992, initiated the international worldwide development in sustainability and especially in the environmental sector. Sustainable development has been discussed and prioritised for years. In food production and handling, sustainable development has not yet been subject to extensive international discussion. This is a way of thinking, which is still new in the food sector, even though it is as important as the development in the environmental area in many ways. Many issues have to be further discussed, including definitions of what is a sustainable, international development in food safety, which goals will be of general importance internationally and where should the resources be used for measuring the development by appointed indicators.

The formulated goals - as well as which activities or initiatives should be started - can be discussed. With joint efforts of food safety experts, consumers and professional organisation, the Nordic countries have started formulating goals seen to be important for sustainable development in food safety.

The process has involved representatives from food producers, retailers, consumer organisations, risk assessors in the areas of toxicology, microbiology and nutrition as well as risk managers and risk communicators. Many of the participants have international expertise and background knowledge and have shared their skills in an active process of developing knowledge-based goals for food safety. In addition, some initiatives on how 
to achieve the goals or sub-goals are formulated and indicators are proposed for measuring of whether the goals or sub-goals are achieved.

The project group had the following participants:

Denmark

Finland

Iceland

Norway

Sweden
Bente Fabech, Danish Veterinary and Food Administration

Lulu Krüger, Danish Veterinary and Food Administration

Jørn Gry, Danish Institute for Food and Veterinary Research

Harriet Wallin, National Food Agency

Franklín Georgsson, Environmental and Food Agency of Iceland; Sigurður Örn Hansson, Veterinary Services

Brynjulf Melhuus, Norwegian Food Safety Authority

Jan Movitz, National Food Administration

Bente Fabech directed the project and Lulu Krüger compiled information and data. The results of the project have been sent to the permanent Committees under the Nordic Council of Ministers and comments have been incorporated in the text.

The Nordic Council of Ministers, the Nordic Committee of Senior Officials and the Committee of Sustainable Development provided funding and approved the results. 


\section{Summary}

The Nordic countries, Denmark, Finland, Iceland, Norway and Sweden published a strategy for sustainable developments in 2001, for 2001-2004. The strategy included food safety, and was the starting point for the work, both in the Nordic countries and worldwide. This work has been followed up, by the Nordic Council of Ministers, by revision of the strategy and by selection of indicators for some of the goals. The strategy and 10 goals are set for 2005-2008 and are based on results from a workshop with participation of authorities, food industry and consumers from all the Nordic countries, followed by consultation of the scientific working groups on toxicology (NNT), microbiology (NNM), nutrition (NKE) and food control (NNK) under the Nordic Council of Ministers.

The goals set up for 2005-2008 are the following:

- Improved efforts for animal health and welfare in relation to food safety

- Strengthen efforts against zoonoses and pathogenic microorganisms

- Strengthen safe food handling and food production in industry and with consumers

- Restrict the occurrence of chemical contaminants and ensure that only wellexamined production aids, food additives and flavours are used

- Increase knowledge and reduce the risk of natural inherent toxicants

- Strengthen efforts for prevention and improve knowledge on diet-related hypersensitivity reactions

- Strengthen knowledge about the relationship between diet, nutrition and health

- Strengthen traceability and in-house control

- Strengthen scientific knowledge of food safety

- Strengthen consumer knowledge

The goals for sustainable development of food safety are listed "from farm to fork". All of the steps and areas are important for food safety and consumer protection. Initiatives are needed in all areas.

The goals are not in prioritised order since the basis for prioritising can be complicated, e.g. should the highest priority be given to risks, which could lead to cancer for very few people or to thousands of cases of serious infections?

Many of the goals are linked and initiatives in one area may then have an effect on risks in other areas.

Indicators for the goals have been selected and data for each indicator were compiled from at least two of the five countries. The indicators selected were chosen to measure 
the effect of initiatives towards an agreed goal or sub-goal in the Nordic strategy. Some proposals for future indicators are also included, but without data.

Indicators should be discussed and new indicators should be chosen when resources are needed in other areas. It should be emphasized that an indicator will be an excellent tool to assess the efficacy of initiatives started to achieve a goal.

Conclusions from the project are:

- Sustainable development in food safety is important for humanity

- Focus on the crucial goals would optimize the efforts made

- Selected indicators provide a tool for measurements of the result of the initiatives

- Selection of indicators provides a measure for correction or change of activities 


\section{Sammenfatning}

De nordiske lande, Danmark, Finland, Island, Norge og Sverige publicerede i 2001en strategi for bæredygtig udvikling, som omfattede perioden 2001-2004. Strategien omfattede bl.a. fødevaresikkerhed og var starten på arbejdet indenfor dette område både i de nordiske lande og internationalt. Nordisk Ministerråd har fulgt op på denne strategi dels ved en revision og opdatering dels ved at udpege indikatorer for nogle af de mål, der er sat. Denne strategi sætter 10 mål for perioden 2005-2008. Målene er udarbejdet som resultat af en workshop med repræsentanter for myndigheder, fødevareindustri og forbrugere i alle de nordiske lande. Workshoppen blev efterfulgt af en høring i Nordisk Ministerråds videnskabelige grupper indenfor fødevareområdet: toksikologi (NNT), mikrobiologi (NNM), ernæring (NKE) og fødevarekontrol (NNK).

Målene, der er sat for 2005-2008, er følgende:

- Øge indsatsen for husdyrsundhed og - velfærd i forhold til fødevaresikkerhed

- Styrke indsatsen mod zoonoser og sygdomsfremkaldende mikroorganismer

- Styrke sikker fødevarehåndtering og produktion hos erhverv og hos forbrugere

- Begrænse forekomsten af kemiske forureninger og sikre at der kun anvendes velundersøgte produktionshjælpestoffer, tilsætningsstoffer og aromaer

- Øge viden og begrænse risikoen for naturlige toksiner.

- Styrke indsatsen for at forebygge og øge viden om kostbaseret overfølsomhedsreaktioner

- Styrke viden om sammenhæng mellem kost, ernæring og sundhed

- Styrke kontrol og egenkontrol

- Styrke den forskningsbaserede viden om fødevaresikkerhed

- Styrke viden hos forbrugere

Målene for bæredygtig udvikling vedr. fødevaresikkerhed er listet fra "jord/hav til bord". Alle trinene og områderne er vigtige for fødevaresikkerhed og forbrugerbeskyttelse, og der er behov for initiativer på alle områder. Målene er ikke prioriteret, fordi kriterier for prioritering er vanskelige at definere, f.eks. er det spørgsmålet om den højeste prioritet skal gives til risici, der kan give kræft hos få mennesker eller til alvorlige infektioner, der rammer tusinder af mennesker.

Mange af målene hænger sammen, og initiativer på et område, kan få en effekt på risici indenfor andre områder.

Indikatorer er valgt under alle mål, og der er samlet data fra mindst 2 af de 5 nordiske lande for hver indikator. Indikatorerne er udpeget med det formål, at man skal kunne måle effekten af de(t) initiativer, der igangsættes for at nå et mål eller et delmål i den nordiske strategi. Under nogle mål er forslag til fremtidige indikatorer, men der er ikke data for disse forslag. 
Indikatorer for et givet mål bør løbende diskuteres, og nye indikatorer bør vælges, hvor der er behov for det på andre områder.

Det skal understreges, at indikatorer er fremragende værktøj til måling af effekten af initiativer, der startes for at nå et mål.

Konklusionerne fra projektet er:

- Bcredygtig udvikling af fødevaresikkerhed er vigtig for menneskeligheden

- Fokus på de vigtigste mål vil optimere de initiativer, der tages

- Udvalgte indikatorer giver et voerktøj til måling af resultater af initiativer mod et givet mål

- Valg af indikatorer giver data til brug for korrektioner eller cendringer $i$ aktiviteter mod et mål 


\section{Introduction}

Sustainable development of food safety is a new issue on the global agenda.

Food safety has always been of importance for the survival of humans. Formerly humans would only survive if fishery, hunting and production of food took place in a sustainable manner. However, in modern time, sustainable development has not been a major issue in relation to food safety.

The Rio-conference on sustainable development in 1992, highlighted the need for international agreement on sustainability, especially in the environmental sector. In this sector, sustainable development has been discussed and prioritised for years.

Sustainable development in food production and handling has not yet been subject to extensive international discussion. The way of thinking is still new in relation to food safety, even though it is in many ways as important as the development in the environmental area. Many issues have to be further discussed, including definitions of what is a sustainable, international development in food safety, which goals will be of general importance internationally and where resources should be used for measuring the development by using agreed indicators.

The Nordic countries, Denmark, Finland, Iceland, Norway and Sweden published a strategy for sustainable developments for 2001-2004. The strategy included food safety, and was the starting point for the work, both in the Nordic countries and elsewhere. This work has been followed up by revision of the strategy and by selection of indicators for some of the goals. The strategy and the goals in this report for 2005-2008 are based on results from a workshop with participation of authorities, food industry and consumers from all the Nordic countries, followed by consultation of the scientific working groups on toxicology (NNT), microbiology (NNM), nutrition (NKE) and food control (NNK) under the Nordic Council of Ministers.

Indicators are parameters chosen in order to follow the results of initiatives started towards an agreed goal or sub-goal. In an ideal world, resources would be found for collecting data on all parameters of importance for measuring of whether a goal is achieved and the results are obtained, but in the real world, the resources are normally not sufficient for such surveillance activities. Therefore, the indicators should be discussed and new indicators chosen when resources are needed in other areas. In many cases, an indicator will be an excellent tool to assess the efficacy of initiatives started to achieve a goal. 


\section{Food safety and sustainable development}

Since World War II, the supply of various foodstuffs has greatly increased. We now have choices of foodstuffs from all over the world - kiwis from New Zealand, exotic fish from Africa, and countless fruits and vegetables from Asia and South America. The growth in international tourism has increased the demand for foodstuffs, which consumers have come to know in distant countries. Simultaneously, transport and technological developments have inhibited, if not prevented spoilage during transportation.

Food technology is under constant development, and new processes are developed to aid solution of old problems. At the same time, however, those new processes can cause new problems. This could also be the case if new biotechnological processes are used, for example, in the production of new foodstuffs through gene modification.

Knowledge in the food safety area is constantly growing. Chemical and microbiological methods of analysis and toxicological and nutritional risk are improved. New safety issues are being discovered, such as the presence of acrylamide as a processing contaminant in, for example, potato-products and dioxin content in fish.

Developments in food selection and growing knowledge create challenges in food safety risk assessment. This development leads to the need for food producers and consumers to obtain new knowledge on foodstuffs, while old knowledge on the correct handling of foods in the kitchen is apparently disappearing from many sectors of society. Many consumers have become much more aware of food quality, while consumers in general have more difficulty evaluating food quality. Food quality covers many elements of importance for consumers. For some consumers, low price is a requirement. However, in general, many associate quality with "safe and honest foodstuffs".

\subsection{Food safety and public debate}

Food safety is important for consumer health, and together with legislation in the area, is important in international trade.

Consumer health is an important aspect for quality of life, and it is essential that consumers can competently take responsibility for, and maintains, their own health.

An important prerequisite for the evaluation of the safety and health-related qualities of foodstuff is that the consumer has sufficient knowledge about foodstuffs. Many consumers lack basic knowledge about handling and preparation of foodstuffs and of the importance of a healthy diet. 


\subsection{Food safety}

The food legislation of most European countries states that only foodstuffs, which do not endanger human health, may be marketed.

Safe foodstuffs can be interpreted as "a diet which has no negative influence on consumer health, neither in short-term nor in long-term perspectives".

This is also a basic principle of the European Union Food Law, and this principle of food safety is the catalyst for the Nordic strategy in this area.

Generally speaking, all foodstuffs are safe if they are ingested in small enough quantities, but at the same time, all foodstuffs are dangerous if the intake is sufficiently high. This applies especially to ordinary food ingredients, such as salt and sugar.

A sustainable development for food safety is one, which maintains safe food and a balanced diet. The development ensures that the total diet does not pose health problems for consumers. At the same time, sustainable development ensures that problems with food safety in this generation are not increased or carried over to the next.

In principle, a foodstuff cannot be risk assessed alone. In most cases, it is important to assess the composition of the whole diet. Some of the factors in foodstuffs, which can influence consumer health negatively, are, for example, a poor nutritional composition of the diet, zoonoses and human pathogens, certain natural inherent toxicants in food plants, and chemical contaminants. In addition, food safety is a matter of avoiding extreme amounts of certain chemicals in foodstuffs, such as, vitamin A.

It is important for consumer health to have a diversified diet and a balanced intake of nutrients and energy. It is important to take the composition of the diet into account when individual foodstuffs and their importance for food safety are assessed. Other issues assessed are:

- Whether a specific risk is acceptable

- Whether the risk is less than the benefit of a specific foodstuff

- Whether different exposures have a synergistic or antagonistic effect, which can influence the risk

Animal health is of importance for food safety for instance, in relation to zoonosis ${ }^{1}$, harmful residues of veterinary drugs, and development of resistance towards antibiotics

\footnotetext{
${ }^{1}$ Zoonosis is any illness and/or infection which likely can be transferred naturally by animals and humans. A zoonotic agent is any bacteria, virus, prion or parasite etc. which likely can cause zoonosis (EU Directive 92/117/EEC).
} 
for instance. New production methods in the primary production of raw materials and within the food industry can lead to a reduction in food safety. Contamination with pathogenic microorganisms must be prevented, as should contamination due to processes such as direct drying, whereby contamination from the drying gases are left in the foodstuffs. Furthermore, food processing can be modified to decrease the formation of contaminants, such as PAH and acrylamide. The content of environmental contaminants and microorganisms in foodstuffs should primarily be limited at the source, that is, either with the contaminator, during primary production, or in the food processing industry. Initiatives should be taken to minimize the content of contaminants in foodstuffs.

Complete removal of all chemical and microbiological contaminants, including natural inherent toxicants in foodstuffs is unrealistic, partly because some contaminants are found naturally and are widespread. Therefore, it cannot be avoided that many contaminants to a certain degree occur in foodstuffs. The Nordic philosophy is based upon the principle that the content of contaminants in food should be as low as reasonably achievable. The question is, to some extent, which risks society would be willing to accept. This is a political decision. It has to be decided which risks would be acceptable and which level is needed for safety. Basically, however, the Nordic countries want a high level of protection.

\subsection{Food production}

The Nordic countries are large producers of foodstuffs. The conditions for producing foodstuffs are of high safety quality. The Nordic countries also have a sound educational system for all its citizens.

There exist sound conditions for sustainable food production, from environmental, safety, social and economic standpoints. Producers realize that it is important to maintain and develop food safety in a sustainable direction. This is not only important for the country's domestic market, but also for international trade.

The fishing and hunting trades of the Nordic countries have special problems relating to food safety because of marine contamination. Only to a minor extent, can these problems be solved by the industry itself. It is essential for food safety that efforts are taken to protect the sea, as well as the land against contamination.

The roles in the work for high food safety are clear. The food business operators importing or producing foodstuffs have the responsibility - within their respective areas - to ensure that food is safe when offered to consumers.

The food business operators must lead the way in ensuring the quality of food safety. There must be openness and credibility encompassing production, and consumers must have the necessary advice on, for example, food handling and preparation whenever needed. 


\subsection{Consumers}

Consumers' choices of foodstuffs and composition of diets play a significant role for their health. A diet balanced in relation to nutrients and energy is of major importance for the prevention of diseases. Thus, it is of major importance that consumers have information that is kept up-to-date and developed. Consumers must have possibilities for the selection of good raw materials, for the composition and preparation of a nutritionally sensible diet, and for avoiding, as far as possible contaminants in the food.

As a minimum, the Nordic consumer must be confident that the food they consume will not lead to illness now or in the future, as long as they follow the advice they get. Consumers must be confident that they are not being misled when buying foods. This is valid for both national and imported foodstuffs, and should also be the case for consumers in countries, to which Nordic foods are exported. At the same time, consumers must take responsibility against any risks due to improper handling and preparation or imbalanced diet.

The consumers must have complete information about the foodstuffs they purchase, including the necessary advice and guidance on the composition of the diet, food processing and food safety.

\subsection{Public officials}

Regulation and information to the food industry and consumers contribute to the development and maintenance of food safety standards. Public officials are responsible for control and for ensuring openness and transparency, both in relation to risk management (regulation and control) and risk assessment. If there arises suspicion regarding the safety of foodstuffs, the authorities have the obligation to take action in a determined and consequent manner, together with the food business operators and, in some cases, together with consumers. Good traceability of foodstuffs shall ensure that potential problems can be solved by removal of the foodstuffs from the market.

The authorities shall contribute to ensuring consumer confidence in Nordic foodstuffs through consequent use of the following principles:

- Demand for high level of protection of consumers

- Openness and transparency in the risk analysis process

- Effective and stringent control using existing legislation

- Accessible information and guidance in all areas of importance for food safety

- Continuous evaluation of initiatives taken to ensure food safety

The ideal scenario would be for authorities, industry and consumers to agree with the goals and implementation plans for food safety. All stakeholders shall actively participate in the risk analysis process. Furthermore, it is essential that all stakeholders actively participate in the international work in this area. Complete openness pertaining to regulations and control and accessible information and guidelines are necessary to 
maintain consumer confidence in the authorities' as being impartial, while ensuring that the food business operators are industry of being responsible participants.

\subsection{Control}

One of the tools, which must have priority in the food industry, is in-house control. A company's in-house control is its guarantee for a food-safety-related evaluation of the critical points in its production, from raw materials to the final foodstuff. Prerequisites for in-house control are systematic knowledge and evaluation of safety in the production of the individual foodstuffs, together with surveillance and documentation of the entire production chain. It is essential for the industry's in-house control that all potential risks are evaluated. In-house control begins with the raw materials used, continues with the evaluation of the applied production method and production hygiene, and covers packaging, storage and distribution of the final food product.

It is the task of the official food control to control the food business operators. This should primarily be carried out by overseeing the industry's in-house control, but also by direct inspection of premises and analysis of the final food. The control shall be effective and prioritized to areas, which by professional evaluation is considered most problematic. Areas related to food safety should have special focus. Well-functioning working environments in the food industry and proper education and supplementary training should be given weight as a prerequisite for food safety.

\subsection{National and international regulations}

Clear and unambiguous regulations, which are understood by industry producers, importers, consumers, and food control authorities, are essential for high food safety, together with advice on food composition and preparation.

Adoption of legislation and guidelines in the EU together with Codex Alimentarius ${ }^{2}$, aims particularly towards higher levels of food safety in relation to free movement of goods. Food producers and consumer organizations should be involved in this work, on both national and international levels.

The Nordic countries participate actively in the development of new legislation in the $\mathrm{EU} / \mathrm{EEA}^{3}$, and contribute actively to the decision-making process in the $\mathrm{FAO}, \mathrm{WHO}$, Codex Alimentarius, $\mathrm{OIE}^{4}$, and in the IPPC ${ }^{5}$. There is participation both in risk management and risk assessment, and it is based upon the principle of the importance of focusing on consumer safety.

The development of the EUs food legislation will continue to be of major importance for development in the Nordic countries. Major parts of the food legislation are harmonized in the EU/EEA, and the development points towards more harmonization

\footnotetext{
${ }^{2}$ Codex Alimentarius is an organisation under the UN's FAO (Food and Agriculture Organisation) and WHO (World Health Organisation).

${ }^{3}$ European Economic Area

${ }^{4}$ International Organisation for Domestic Animal Illness.

${ }^{5}$ International Plants Protection Convention.
} 
within the area. The work in the EU is, therefore, of importance to all the Nordic countries, and it is important that the Nordic countries actively influence the EU towards the goals and values set in the north for sustainable development of food safety. This pertains to regulation of foodstuffs and the efforts for preventing contamination of the environment and of the raw materials in the primary production. The Nordic countries have special views on problems in several areas, and it is of relevance to join efforts in the activities of influencing the international development as much as possible in the direction desired by the Nordic countries. There is strength in countries' joint efforts toward common goals.

Food safety has gained international importance with the demand that the Codex Alimentarius standards serve as the basis for requirements in international trade in the WTO and SPS $^{6}$ agreements. Thus, risk assessment based on scientific documentation becomes conclusively important for possible trade restrictions. Countries with a high protection level similar to the Nordic countries can thus be pressured when the risk analysis includes factors other than scientific risk assessment. This could include the socalled "other legitimate factors," like GAP (Good Agricultural Practice) or animal welfare and ethics. The Nordic countries will continue active participation in the cooperation on Codex standards in order to get standards adopted which ensure high safety protection levels and include other legitimate factors.

\subsection{Activities and initiatives to date}

Food safety and food quality have been the centers of attention in the legislation of the Nordic countries for many years, and are also the centers of focus in the politics on foodstuffs in these countries. These areas have, and remain, central in the cooperation on the Nordic Council of Ministers and especially in the Nordic Committee of Senior Officials for Food Issues, which has had several important activities in the area for many years. Food safety is of high priority on the political agenda, and in the Nordic countries decisions are made concerning food safety and consumer influence.

Minister declaration for increased food safety in the Nordic countries ${ }^{7}$

Food safety is listed high on the political agenda in the Nordic countries, in the EU, and internationally. In 2002, the Nordic ministers of food adopted certain initiatives and decided that:

The Nordic countries shall strive to cooperate toward improving influence in international organizations, and the established Nordic fora of cooperation on all levels should pay attention to the possibilities the cooperation creates. Cooperation should be actively practiced within the frames of the permanently established and ad hoc networks, and with continuous contact aim for solutions of acute problems of common interest. The Nordic official committees in the food area - EK-Livs, NEF and NEJS, shall have as their special responsibility, to ensure:

- Continuous evaluation and selection of issues, for which the Nordic countries should join their efforts to get influence;

\footnotetext{
${ }^{6}$ Sanitary and Phytosanitarian Measures

${ }^{7}$ The Greenland Declaration, 23 August 2002.
} 
- Create fora toward documents with goals, guidelines and basis for each theme, when necessary. The documents have to be adopted and forwarded to the individual authorities in the Nordic countries, and should be used internationally;

- The Nordic countries will strive to ensure effective national consumer influence in the food area, Nordically, and internationally, e.g. by achieving the recommendations in the Nordic plans of action on strengthening consumer influence in the food area.

Food safety should, whenever possible, be included as an important element in future Nordic projects. Examples of important areas of cooperation include meat control, traceability, dioxins, natural inherent toxicants, and zoonosis.

The Nordic countries have adopted an action plan for strengthening consumer influence in the food area, which, as part of its wording, states:

The Nordic action plan for strengthening consumer influence in the food area ${ }^{8}$

Consumer influence is important in the food area for two reasons. Firstly, it should be ensured that consumers take a stand on proposals and initiatives from authorities. Secondly, it should be ensured that consumers take responsibility for their part of the food chain, "from farm to fork", including diet composition.

In 2002, the Nordic ministers of food adopted an action plan recommending that Nordic authorities work within the below-mention four goals to ensure that consumers are able to influence food policies in the Nordic countries.

It is the Nordic countries' intention to ensure effective consumer influence in the food area, nationally, Nordically, and internationally, e.g. through working towards the realization of guidelines for a proposal for a Nordic action plan on strengthening consumer influence on food policies.

1. Increased knowledge among Nordic consumers in the food area

2. To ensure mutual openness among authorities, industry, and consumers

3. To contribute with resources for consumer involvement

4. To create meeting fora for dialog and agreements between consumer interests, industry, and authorities

There are new initiatives also in the research area. Under the Nordic Industrial Fund has been developed a twofold strategy in corporation between several national research institutions and the food sector. The purpose is to solve the challenges to food safety.

1. Via a Nordic bridge-building program "Processing for food safety" an effective and competitive research section should be established within selected issues of importance for consumers and the food industry:

${ }^{8}$ The Greenland Declaration, 23 August 2002. 
- Risk analysis

- Risks in food production (reduction of chemical contaminants formed during processing

- Traceability

- Campylobacter

In 2004 several larger research projects are started which support the activities within the Nordic corporation on food safety.

2. A EU funded project (PROFORSAFE) was started in 2003. The Nordic research administrations and Nordic researchers shall create a platform to enlarge the Nordic program for building bridges and start a five years network between European research programs on food safety. More than twenty countries are participating in the application to the ERA cluster "SAFEFOODERA".

Furthermore, the Nordic Committee of Senior Officials for Food Issues has reviewed research designated for risk managers and has formed an ad hoc working group for joint research and educational discussions for fishery, agriculture, forestry and food.

\subsection{Long-term measures for sustainable development}

The long-term measures for sustainable development begins with the strategy's definition of sustainable development for food safety.

The superior goals for legislation and control are fixed:

a. Consumers shall have safe foodstuffs, information, and the possibility of putting together a healthy diet

b. Legislation shall be adopted based on dialog with consumers and industry

c. Advice and guidelines shall be elaborated, which are informative and easily accessible for food business operators and for consumers

Consumers shall have the opportunity for realistic and educated choices when putting together healthy and balanced diets. This shall be achieved through basic knowledge and information, including sufficient and easily understandable food labelling.

Producers and importers are responsible for the foodstuffs being in compliance with legislation. The official food control must ensure that the goals are achieved. 
In cases where a direct connection is found between environmental contaminants, production, conditions, and food safety, it is the principal responsibility of the producers that the foodstuffs are safe.

In this connection, it is important that agriculture and fisheries are not negatively affected by food contaminating factors in the earth, air and sea, but that contamination is to be stopped at the source.

Initiatives aiming at maintaining, and preferably improving, food safety for future generations should be strengthened. 


\section{Goals and indicators for each goal}

\subsection{Targets and measures 2005-2008 - a general introduction}

The overall goal for food safety shall be guaranteed "from farm to fork". Assessment of food safety is increasingly based on risk assessment in international fora, especially in the expert committees of EU and FAO/WHO. It is important for international trade that the same standards for food safety are accepted worldwide. At the same time, it is essential that these standards are elaborated and based on an overall demand for a high level of consumer protection. International risk management and knowledge building is achieved in cooperation with countries all around the world. Increased influence on decisions is achieved by prioritized active participation in the work. There is also a need for cooperation between industrial and consumer organizations to ensure a wellbalanced effort with regard to consumers and the industry.

Generally, the Nordic countries work jointly to promote Nordic influence in international risk analysis process throughout the EU and the FAO/WHO expert committees. For this reason, it is important to maintain and develop qualified knowledge on food safety in the Nordic countries and to increase international cooperation so that the countries can make a joint international contribution. The Nordic countries shall participate actively, also with qualified contributions to the decision process. Formal and informal international networks shall be maintained and, if possible, further developed, and it should be ensured that the concerned industry and consumer organizations are involved and participate in the process of developing legislation and advice.

The basis for the decision-making process should be open and transparent. If food security is occasionally given a higher priority than food safety, the consequences should be considered and mentioned in the decisions.

It is assumed that in the near future there will be a demand for a number of initiatives. The strategy lists a number of primary goals based upon the "from farm to fork principle". The goals are interconnected and together constitute primary goals important to achieve in order to ensure a sustainable development of food safety. The goals are not based upon priorities; however, it should be highlighted that nutrition and diet are essential elements of consumer safety.

The overall target goals can consist of several sub-goals, and it is important to have indicators and methods to measure the effects of initiatives that are taken to achieve a goal or a sub-goal.

\subsection{Indicators - which, when and how}

The Nordic strategy for sustainable development of food safety has a list of goals. For each of these goals, indicators ought to be selected as useful tools for measuring society's movement towards a sustainable development of food safety. Indicators are used to measure the effect of the initiatives and activities and to follow whether these activities lead to the initiated goals. Furthermore, indicators can also be used to compare 
the results of the activities in the Nordic countries. Indicators could also be called measurers of effects, since they measure the effect of the initiatives taken.

An indicator can be defined as:

"A parameter showing the development in a situation or connection in relation to the realization of important goals or initiatives."

In an ideal situation, the data used for the indicator should be collected over a 3-5 year period, in order to show whether the development is moving in a positive or negative direction.

\subsection{Comparison of data}

In the selection of indicators, different considerations should be made to ensure that the data are comparable both in practice and in theory.

Ideally, it should be known:

- How sampling or data collection is performed

- The method of analysis used, and

- Whether there were uncertainties in the analysis.

When data are used in comparisons or to follow a development, for instance, between countries or of a general development over time, it is essential that the data used are the results of similar sampling types and methods of analysis. Sampling is important, i.e., because chemical and microbiological contamination in food is not always homogenous.

In consumer surveys, it should be ensured that a broad selection of the population and a sufficient number of people are surveyed to ensure significance of the result.

Sometimes it is necessary to select indicators and compare data with dissimilar backgrounds. In such cases, any uncertainty must be taken into account when coming to conclusions.

\subsection{Surveillance data versus control data}

Control data can give an incorrect picture of the situation, because control is often based on sampling in light of qualified suspicion. Therefore, non-compliances found in a control project of, for example, maximum levels would not necessarily indicate the same result if all the foodstuffs were to be analyzed.

Some data are collected because of requirements in, e.g. EU directives or regulations. Some of these data are not necessarily data, which would have been given priority in accordance with the strategy.

The indicators could be divided into the following groups: 
- Necessary/essential key information for following the development of one goal for food safety and sustainable development

- Basic/fundamentally important information for following the development of one goal for sustainable development and food safety

- Useful information for following the development of one goal for sustainable development and food safety

Ideally, all areas of importance for food safety should be followed using selected indicators. In reality, the available resources must be prioritized. It is important that decisions are taken in conjunction with the timeframes for the activities or initiatives. The measurements of effect should be followed up by an evaluation of the activity. If an activity does not give the desired effect, and thus fails to reach the desired goal, it should be considered whether the activity is optimal. If the activity turns out to reach its goal, it should be considered for how long the activity should continue.

Indicators should be selected in connection with specific sub-goals and activities, which have been initiated in order to achieve the goal. Also, the indicators should be subject to continuous evaluation for usefulness and resource demand.

\subsection{The goals and proposals for present and future indicators}

The goals for sustainable development of food safety are listed "from farm to fork". All of the steps and areas are important for food safety and consumer protection. Initiatives are needed in all areas.

The goals are not in prioritised order since the basis for prioritising can be complicated, e.g. should the highest priority be given to which could lead to cancer for very few people or to thousands of cases of serious infections?

Many of the goals are linked and initiatives in one area may have an effect on risks in other areas.

The Nordic countries have adopted the following goals for sustainable development for food safety:

\section{Goal: \\ Improve efforts for animal health and welfare in relation to food safety}

Healthy domestic animals ${ }^{9}$ are important for food safety. Healthy domestic animals that have living conditions that ensure their welfare will have less need for medical treatment, which in turn reduces the use of drugs. The lesser drugs used, the lesser is the risks of drug residues in the foodstuffs, and the lesser the risk for developing resistant to

\footnotetext{
${ }^{9}$ Domestic animals also includes aquacultural animals from fish farming and marine farming.
} 
pathogenic microorganisms. Furthermore, healthy domestic animals generally lead to less of a risk for foodstuffs of animal origin that could endanger human health.

Farmers and other primary producers have a responsible toward food safety in the farmto-fork chain. They shall have goal-oriented information on the importance of animal health for food safety and on their responsibility in that regard.

The goal is to guarantee preventive efforts in the primary production toward diseases, zoonoses, and other circumstances that pose problems for animal health and food safety.

This can be achieved by training all food business operators ("from farm to fork"), especially primary producers. In addition it should be ensured by control that problems are tackled at the source.

\section{Proposal for future indicators}

\section{Percentage of abnormal death among domestic animals}

Background

Abnormal death among domestic animals is an indicator of animal health and in some cases also of animal welfare.

\section{Percentage of animals with registered symptoms of diseases in slaugtheries}

\section{Background}

Percentage of animals sent to slaughtering with symptoms of diseases is an indicator of health in the primary production of animals for human consumption.

\section{Percentage of ruminants carrying enterotoxin producing Staphylococcus aureus}

\section{Background}

The percentage of ruminants with entrotoxin producing Staphylococcus is an indicator of zoonosis in the primary production.

\section{Amount of antibiotics given to domestic animals}

Background

As use of antibiotic should be an indication of diseases among domestic animals, the amount of antibiotics used would be an indicator of animal health.

\section{Goal:}

Strengthen efforts against zoonoses and pathogenic microorganisms 
The spreading of food-borne pathogens takes place during primary production and food production - in industry, restaurants, cafeterias, and similar places, and also in food preparation in the home. Poor quality raw materials can lead to pathogenic microorganisms in the final foodstuffs.

The protection level in the Nordic countries shall be strengthened as much as possible, and it is important to work for harmonization in the EU and Codex Alimentarius occurring in such a way that the Nordic countries will not see a decrease in the protection level. Harmonization of the legislation should not be a barrier to progress in the area.

Consumers shall have adequate information on hygienic preparation of food in the home. Surveillance of food-borne diseases and pathogenic microorganisms shall be intensified to reveal the roots of, and the causes for, the spreading of diseases. Examples of such bacteria are Salmonella, Campylobacter, Listeria, and Yersinia.

The goal consists of initiating strategies for the reduction of zoonosis in the primary production and the food industry. Initiation of these strategies should take into account the potential problems from raw materials, final products, and drinking water, and should be documented by surveillance. Drinking water should comply with requirements adopted in the EU. In countries where surface water is used, supplementary requirements could be necessary if the water is used in food production. 
Indicators selected under this goal are the following:

Number of human cases of Campylobacter (per 100.000 inhabitants)

Total number of cases:

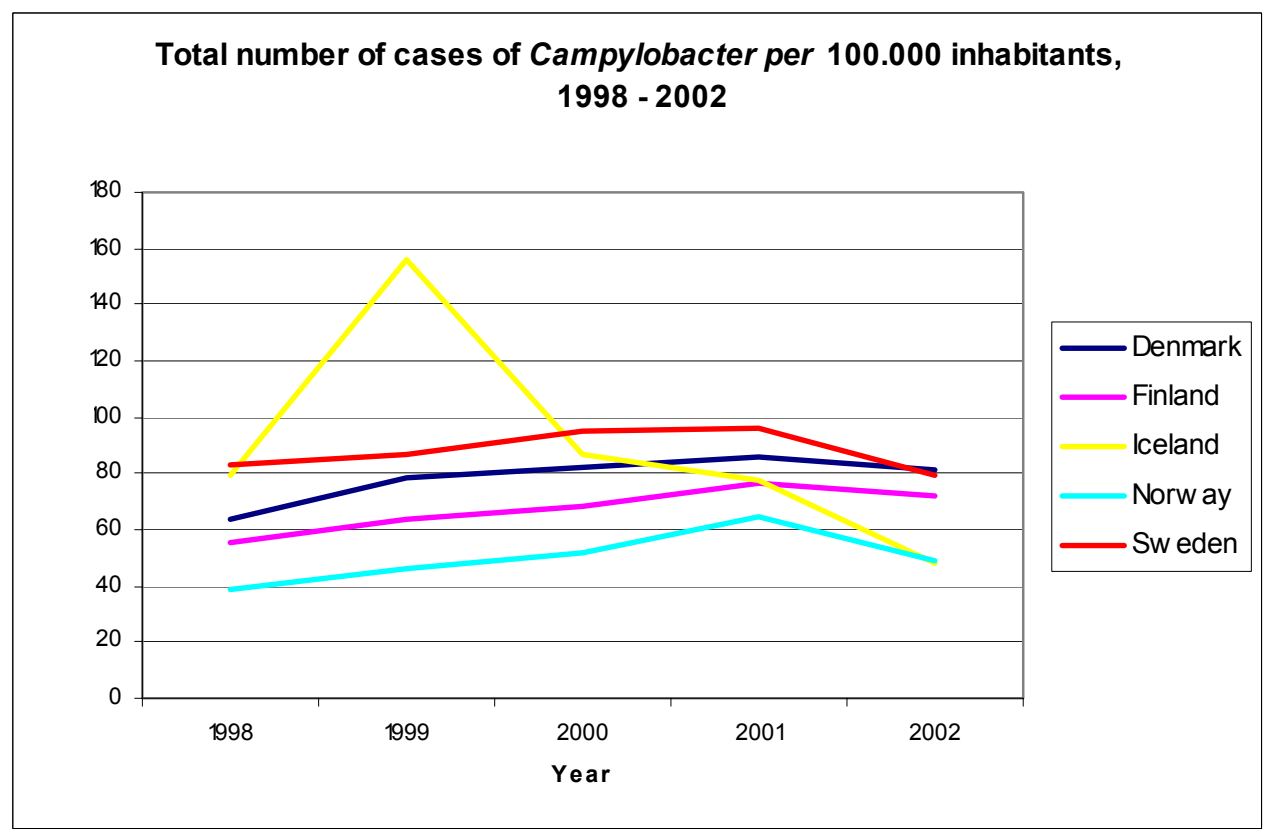

Number of human cases of Campylobacter (per 100.000 inhabitants), national cases:

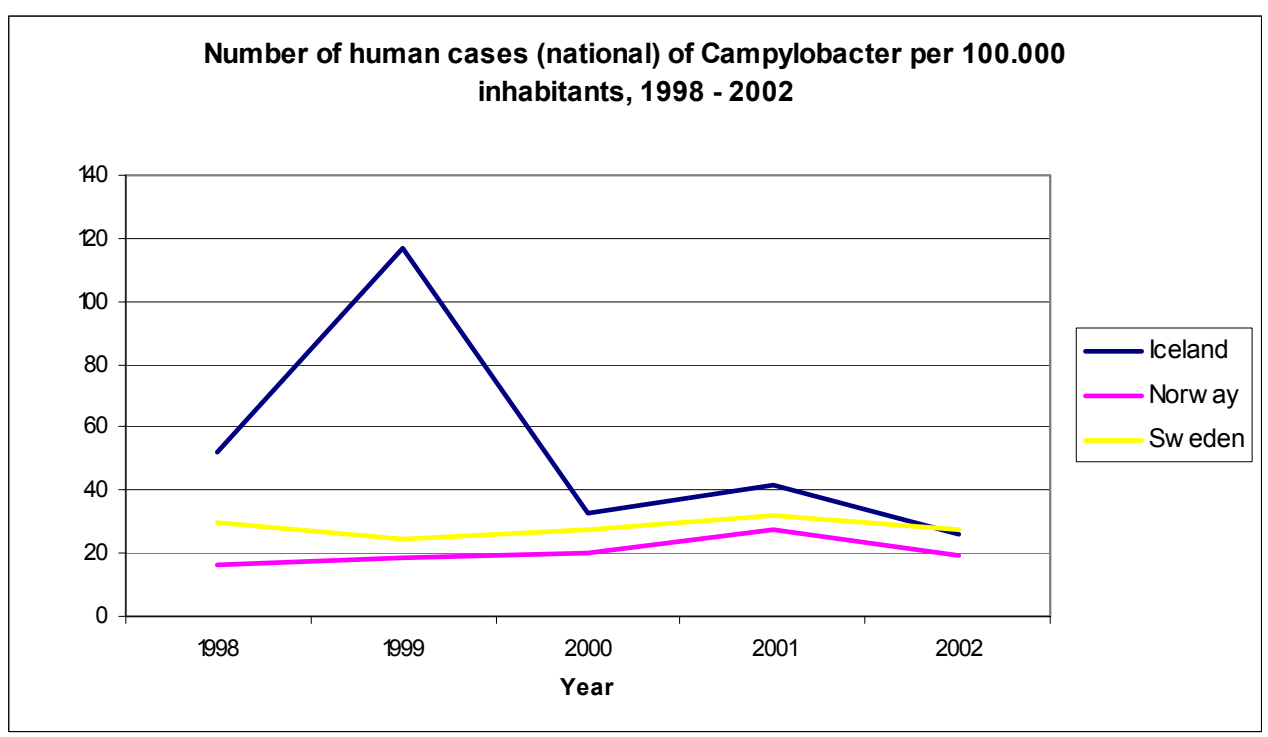


Number of human cases of Campylobacter (per 100.000 inhabitants), cases acquired abroad

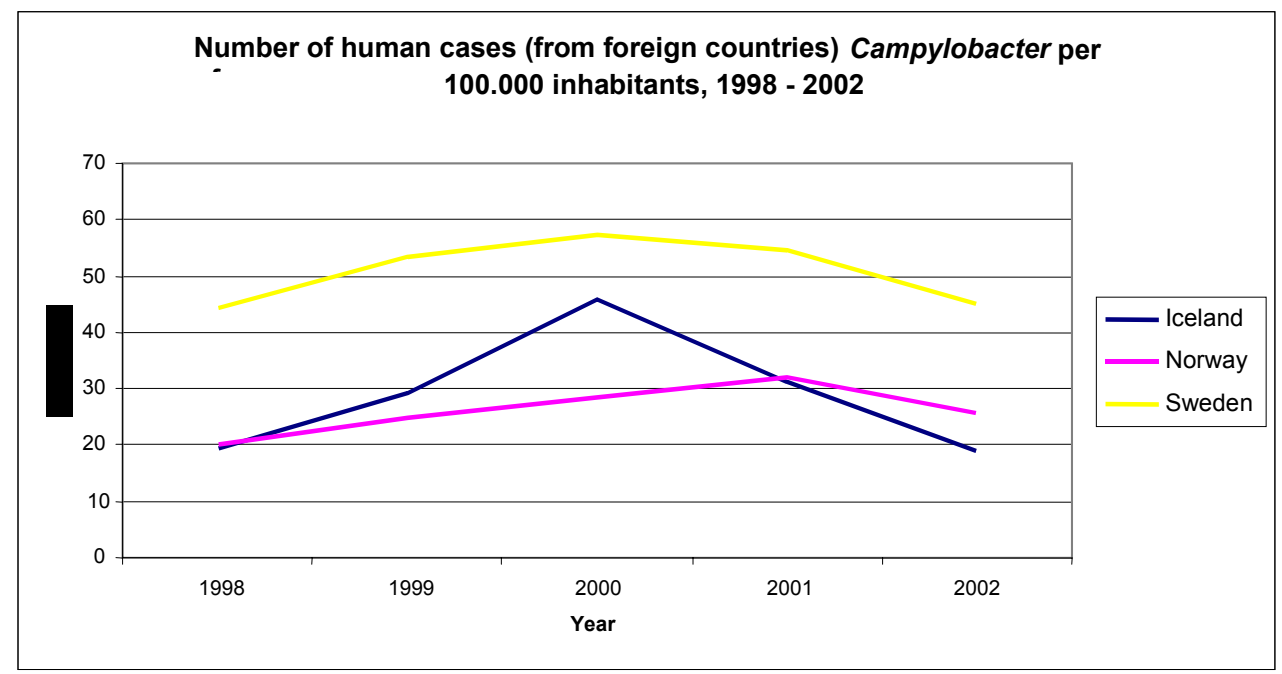

Number of human cases caused by Salmonella (per 100.000 inhabitants)

Total number of cases:

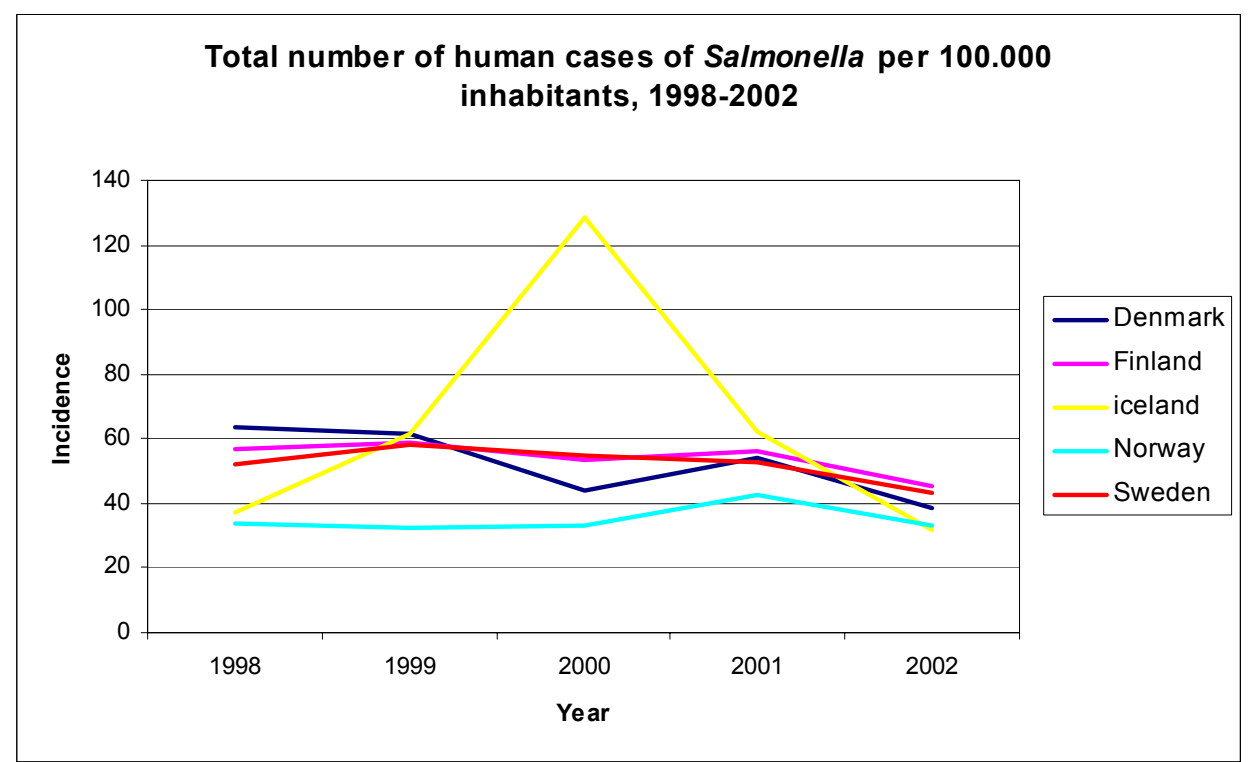


Number of humane cases due to. Salmonella (per 100.000 inhabitants), national cases:

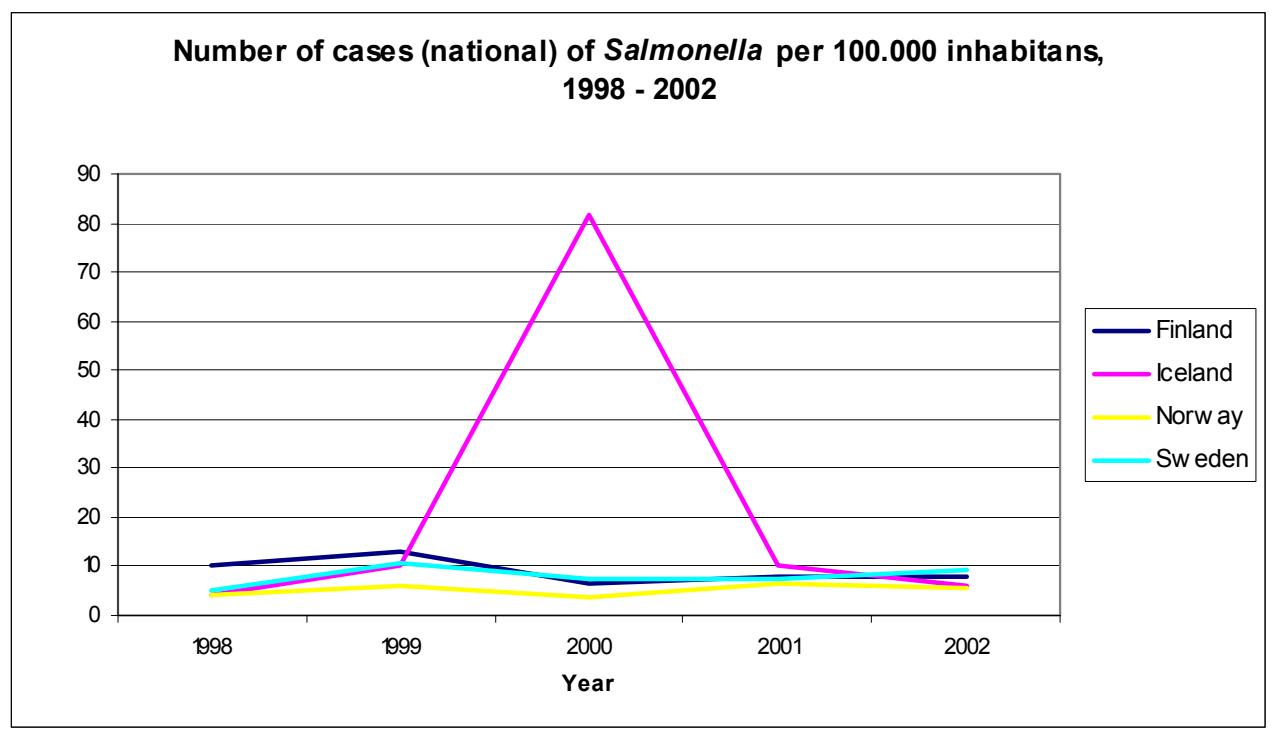

Number of human cases of Salmonella (per. 100.000 inhabitants), cases acquired abroad:

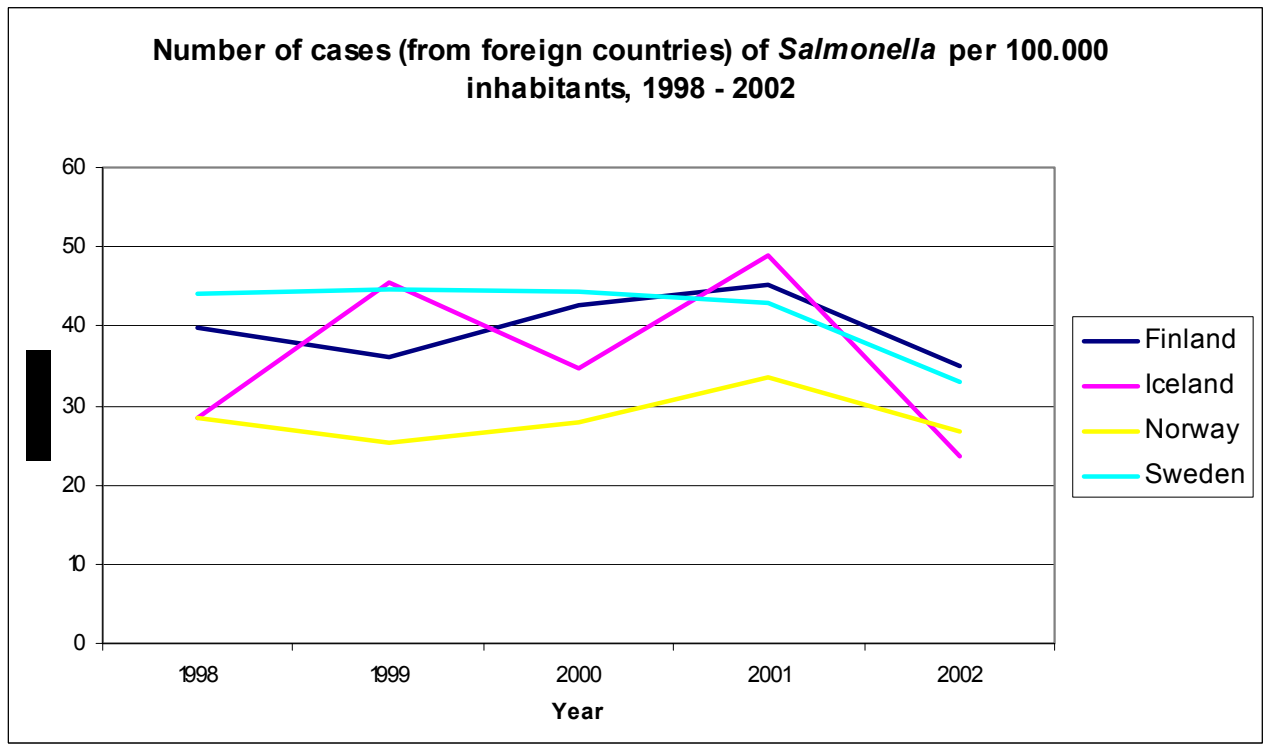




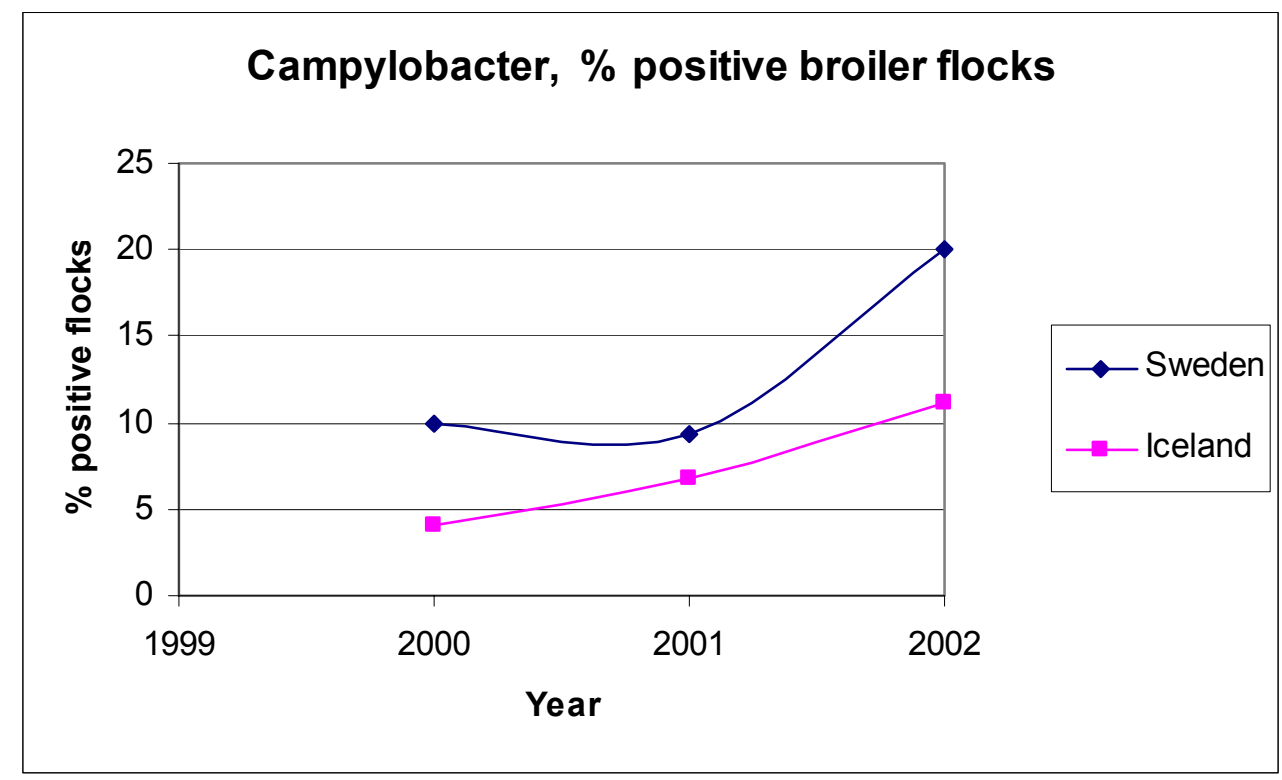

\section{Background}

The indicators are chosen to monitor the sub-goals under this goal, i.e. Salmonella and Campylobacter that are important zoonotic agent and responsible for foodborne diseases. Initiatives have been taken to reduce these zoonosis and reduce the number of food born diseases caused by Salmonella and Campylobacter. Data for the indicators, number of human diseases caused by Salmonella, Campylobacter over years show that the initiatives have had positive effects. Concerning Campylobacter in broiler flocks, the increase in 2002 in Sweden reflects a new method of sampling. 


\section{Proposal for future indicators}

\section{Surveillance of resistance pattern in microorganisms}

\section{Background}

This indicator is proposed in order to be able to follow the growing problem of resistance against antibiotics.

\section{Number of $E$. coli in drinking water, as an indirect indicator of enteropatogenic microorganisms.}

Background.

In some of the Nordic countries, drinking water is covered by the legislation on foodstuffs. Drinking water in the Nordic countries is tested regularly in accordance with EU directive for E. coil, which is an indicator.

\section{Number of registered food-borne diseases and outbreaks caused by microorgan- isms*}

\section{Background}

The number of registered food borne diseases and outbreaks caused by microorganisms is an indicator of acute food-borne diseases.

Number of Salmonella in fresh meat (pork, beef, sheep etc.)

\section{Background}

The number of Salmonella in fresh meat is an indicator of a zoonosis in meat.

\section{Goal:}

Strengthen safe food handling and food production in industry and with consumers

Food is the source of a large number of diseases caused by microorganisms. Some of these microorganisms are naturally found in the environment, while others are found in food, due to poor hygiene in food preparation. Safety in the handling of foodstuffs is a condition, which can prevent chemical contamination, foreign bodies, and the transfer of residues of foodstuffs, e.g., powder from nuts, which can cause allergic reactions among some consumers. Furthermore, correctly done, food production is also an important factor for the prevention of contamination with natural toxins.

For example, the correct preparation of beans should be guaranteed. This is important in the industry and among consumers.

The Nordic countries will work for reducing contamination of feed and raw materials in the primary production, where contamination can cause problems for food safety under industrial processing and in the preparation of food by consumers at home. In the case of food production, this can be done by introducing and/or expanding training courses 
for industry personnel. Parallel to this, better traceability, $\mathrm{HACCP}^{10}$, and ledgers for contaminant sources will be introduced. This is to prevent occurrence of

microorganisms in foodstuffs, and to reduce the number of food-borne diseases caused by pathogenic microorganisms. In addition, hygienic and safe production is the basic element of importance in the in-house control of food business operators. It is also important in relation to chemical contaminants, foreign bodies, and allergies.

The goal is to increase knowledge among personnel involved in the primary production, as well as in industrial production, among retailers and consumers, in order to ensure education of possible risks.

All consumers shall have the possibility of getting basic information on foodstuffs, including information on the importance for hygiene during food preparation. In this way, consumers will have a basis for safe food handling.

\section{Proposal for a future indicator}

\section{Number of Salmonella in fresh poultry and broiler flocks}

\section{Background}

The number of Salmonella in fresh poultry meat and broiler flocks is an indicator of a zoonosis in poultry.

\section{Goal: \\ Restrict the occurrence of chemical contaminants, and ensure that only well-examined production aids ${ }^{11}$, food additives, and flavours are used}

Chemical contaminants in foods are undesirable, and consumers in the Nordic countries generally demand that foodstuffs are as free from contaminants as possible. Chemical contaminants can affect consumers' health.

In addition to the effects that individual chemicals can have on consumer health, many chemicals can have special combined effects, and consumers shall be protected against any harmful substances.

Environmental contaminants can be found in foodstuffs and can affect food safety, and must be stopped at the source of contamination.

Environmental contaminants are not always avoidable, and can be found in seemingly healthy foodstuffs.

\footnotetext{
${ }^{10}$ Hazard Analysis of Critical Control Points

${ }^{11}$ Production aids include in this context pesticides, veterinary drugs, and residues from cleaning materials and desinfectants.
} 
Many countries and international organizations, for example collect data from environmental surveillance, data collecting on the marine pollution in the Baltic Sea. Whenever possible, these data should be incorporated into the documentation for the risk assessment of foodstuffs.

Contaminants can also be formed during food processing under conditions such as high temperatures, when components problematic to food safety can be formed, e.g. acrylamide and frying mutagens. Changes in the process conditions can reduce the content of such substances. Furthermore, contamination can stem from the use of food packaging and other contact materials. Food packaging protects foodstuffs from outer contamination, including microbiological contamination. However, components from the packaging materials can migrate into the food and contaminate the food. Most food contact materials are produced from well-known chemicals, and initial actions can possibly prevent this contamination. Correspondingly, food packaging is a potential problem for the environment, where packaging is often left. Chemicals used in food packaging shall be assessed in relation to their life cycle. Chemicals, like flavourings, food additives, production aids, such as pesticides and components in packaging, are added to foods or used in relation to the production of foods. These chemicals shall be risk assessed and/or approved before use, and it must be required that they are safe.

It is the responsibility of food producers to ensure that foodstuffs are safe, and risk assessment of the chemicals used must be performed, if prior national or international expert committees have not carried out assessment.

The Nordic countries will continue working to ensure that the use of production aids like pesticides, veterinary drugs and cleaning and desinfection aids, are reduced to the technologically achievable minimum.

Risk assessments of chemicals used in, for example food packaging or as flavourings, are often non-existent, and shall be prioritized. Chemicals, which pose safety concerns, shall be substituted with less dangerous chemicals. This would also be relevant for substances problematic in relation to the environment or worker protection.

The Nordic countries should use all available data for the risk assessment of chemicals in food, whether they are contaminants added.

The goal is to minimize as far as possible the occurrence of chemical contaminants in food. This should be the case both for environmental contaminants and chemicals migrating from food packaging materials.

Consumers shall have advice and guidance to be ensured a limited exposure to substances of health concern, and at the same time a balanced intake of nutrients, for instance from fish.

Process contaminants should be reduced by selection of optimal processes, such as temperatures, which lead to a minimum content of substances that endanger human health, for example, acrylamide.

Another goal is that all flavours - not only chemically defined flavouring substances should be risk assessed, and control measures for flavours be developed. Food additives, including processing aids, veterinary drugs, and pesticides should be assessed or reassessed whenever new knowledge becomes available. 


\section{Indicators selected under this goal are the following:}

The number of risk assessments of chemically defined flavourings in percentages of flavourings used

\section{Number of risk assessments of chemically defined flauvourings used.}

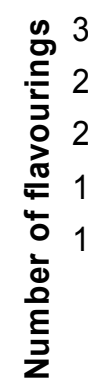

3000 2500 2000

1500

1000

500

0

$\square$ 2005-2006

$\square 2004$

$\square 2003$

$\square$ 1996-2002

\section{Year}

Background

Chemicals like flavouring substances that are directly added to food shall be safe. The industry claims that in total approximately 2500 substances are used in food. The risk assessment takes place in expert committees of the EU and in FAO/WHO.

The indicator shows the development towards completed risk assessments of all chemically defined flavours used in foodstuffs in Europe. 


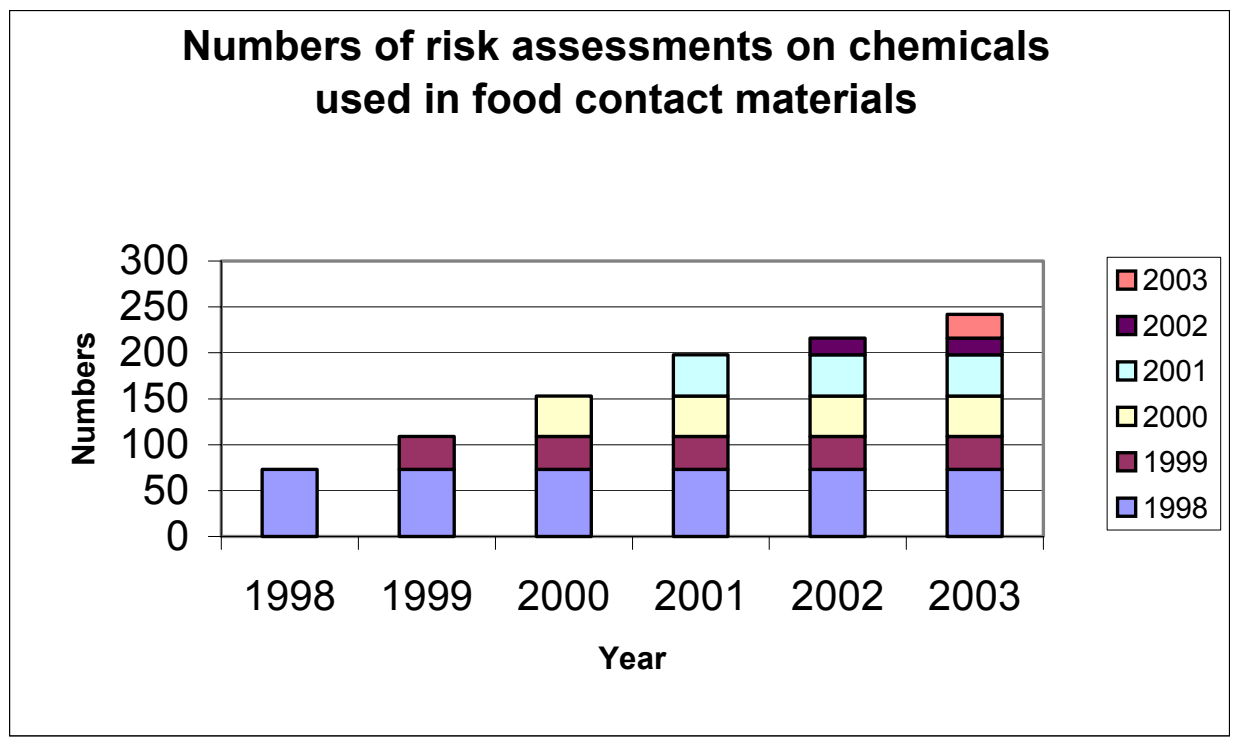

Number of risk assessments of chemicals used in food contact materials

\section{Background}

Chemicals migrating from food contact materials shall not endanger human health. It is estimated that approximately 3500 chemicals are used in plastics, and many chemicals are used in other materials like surface coatings, paper, silicones etc.

The risk assessment takes place in EU's EFSA. The indicators show the development in the risk assessment towards completed risk assessments of all chemicals used in food contact plastics.

Occurrence of residues of production aids in foodstuffs

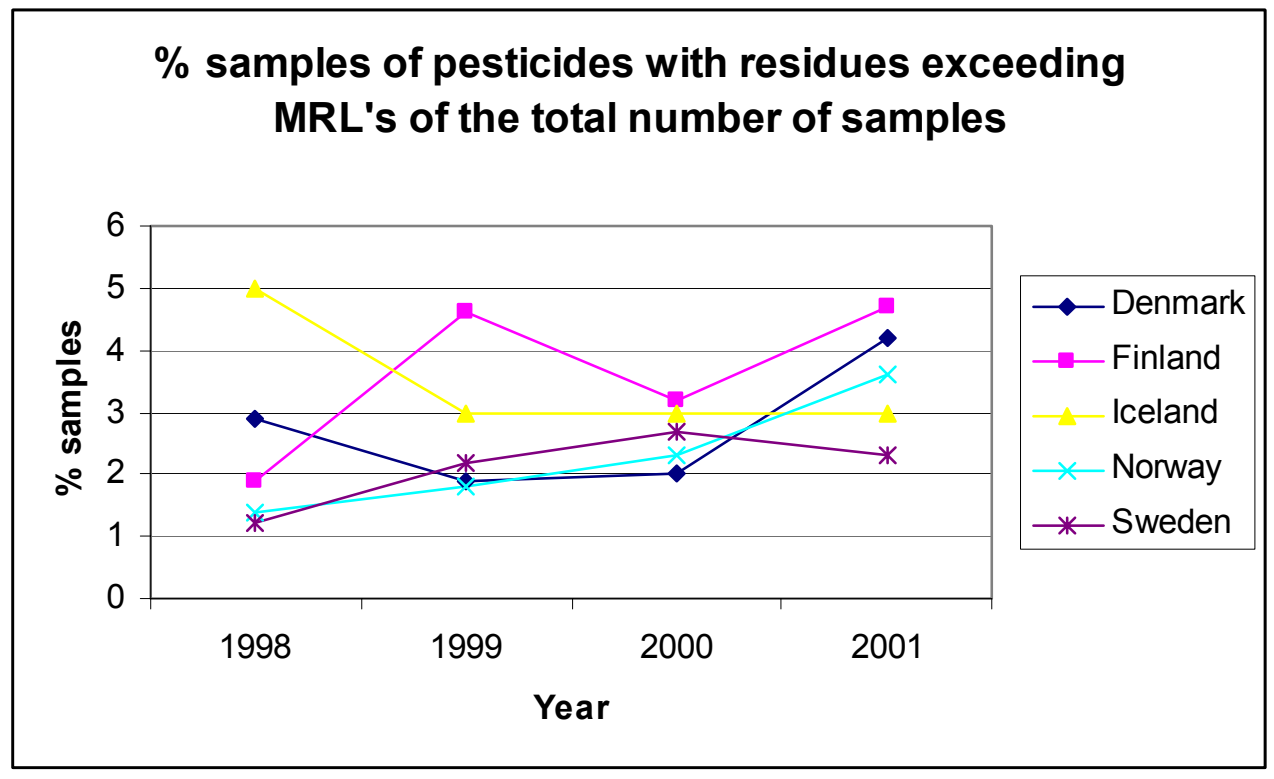




\section{Background}

Chemicals like pesticides that are used directly in the food production and found as residues in the food shall be safe and their levels in foods shall not exceed the maximum levels laid down in legislation. The indicators show the number of samples of foodstuffs exceeding the maximum residue level (MRL).

\section{Proposals for future indicators}

\section{Content of dioxins and dioxin like PCB's in mothers milk}

\section{Background}

Dioxin and $P C B$ 's are indicators of environmental contamination and are found in several food types and also in mothers' milk. Several countries analyse and collect data as indicator on these contaminants.

\section{Data from the marine environment}

\section{Background}

Data on contaminants in the marine areas are collected by several international organisations such as ICES (the International Council of Exploring the Sea). These data could be used as an indicator in order to follow the situation of contamination of the marine areas and to illustrate the potential contamination of seafood products.

\section{Occurrence of residues of veterinary drugs in foodstuffs (antibiotics)}

\section{Background}

Chemicals like veterinary drugs used in the food production and found as residues in the food shall be safe and their levels in foods must not exceed the maximum levels laid down in legislation. The indicators should show the number of samples of foodstuffs exceeding the maximum residue level (MRL).

\section{Goal:}

Increase knowledge about and reduce the risk of natural inherent toxicants

Inherent natural toxicants are found in many foodstuffs, mainly in food plants, but also in certain fish species and edible mushrooms. They differ from contaminants, partly because they are unavoidable, and partly because they have both positive and negative effects.

Some inherent toxicants function as "natural" pesticides and protect plants; others have important organoleptic properties, for example in potatoes and cabbage. The inherent toxicants can have acute toxic effects, for instance, lectins in beans. Others have longterm effects, like furocumarins in celery. As some of the inherent toxicants are 
destroyed during processing, it is essential for consumers to have readily available advice and information on correct food handling at home.

The Nordic countries will ensure that consumers are protected against health-damaging effects of inherent toxicants, and furthermore, that the substances are maintained at an acceptable level in foodstuffs, due to their positive effects.

The content of some of the substances could be increased or decreased, for instance, by genetic modification. The Nordic countries will ensure that the content of harmful substances will not be increased and/or that no new inherent toxicants are formed when new plant species are developed in comparison with the content in the traditional food plants.

The goal is to increase the knowledge among personnel in the food industry and consumers about inherent natural toxicants, and thus reduce the intake of these substances. This shall take place through education and information. There is a need for increased research in the field of inherent natural toxicants.

Knowledge will be an essential prerequisite for the assessment and control of new foodstuffs, for instance, foodstuffs produced by the use of genetic modification.

\section{Proposal for future indicators:}

Number of critical risk assessments of substances in health food as result of Nordic co-operation

\section{Background}

Inherent toxicants in health foods can cause food safety problems. The Nordic countries have co-operated in the area and continue to do so. The indicator should show the development in the results.

\section{Number of critical assessments of the occurrence and toxicity of bioactive compo-} nents in food plants and edible mushrooms as a result of the Nordic co-operation.

\section{Background}

Bioactive components in food plants and edible mushrooms can cause food safety problems. The Nordic countries have co-operated in the area and continue to do so. The indicator should show the development in the results.

\section{Goal:}

Strengthen efforts for prevention, and improve knowledge on dietrelated hypersensitivity reactions

Food is a serious problem that is mainly related to normal ingredients in foodstuffs, like wheat flour and hazel nuts. Sufficient information on the composition of foodstuffs enables the consumer in most cases to avoid allergic or intolerance reactions. 
The industry shall ensure that food ingredients are not transferred as contaminants between productions, thereby constituting a risk for reactions among allergic persons.

Diseases due to allergy reactions are registered nationally in the extent that they are reported. The Nordic countries should work for a systematic reporting of allergic reactions from medical doctors in the same way as the reporting is done for microbiological diseases.

The goal is to achieve prevention through information about food ingredients and by sufficient food labelling. In food production, allergens and intolerance-causing ingredients should be part of the in-house control programmes of food business operators.

The basic knowledge should be communicated to the population as a part of the normal school education. This basic information should be supplemented by easily accessible information from authorities including knowledge of relevance and importance for all consumers.

It is a simultaneous goal that consumer information result in the reduction of diseases caused by hypersensitivity.

\section{Proposal for a future indicator:}

Number of allergic cases caused by foodstuffs (including anaphylactic chock) requiring medical treatment

\section{Background}

Allergic reactions caused by components in foodstuffs are managed by giving information to medical personal and consumers. Registration of cases, which require medical treatment, will be an indicator of the results of prevention via information.

\section{Goal:}

Strengthen knowledge about the relationship between diet, nutrition, and health

Scientific reports from the entire Western world show that the composition of the diet is of major importance for consumer health. Diet-related diseases, such as obesity, are increasing significantly, and are expected to considerably increase the frequency of other diseases if the development is not curbed through change in diet and increasing physical exercise. Energy distribution and diet composition, in particular, are important for the development of the "major" lifestyle diseases, such as cardio-vascular illness, cancer, and obesity. Alone in Denmark, it is estimated that up to 65\% of deaths in 1998 were related to cardio-vascular diseases or cancer.

The effect shall, e.g., reduce the intake of sugar and fat, increase the intake of fruit and vegetables, and motivate the population to increase physical activity. Healthy foods should be offered in schools in order to increase the possibilities for school children to eat healthy foods. 
Furthermore, it is essential that the efforts include the assessment of fortified foodstuffs, with the understanding that nutrition can have negative effects on consumer health if ingested in too large amounts.

An introduction of new foodstuffs with special claims on health effect, will demand special initiatives, including that health claims be scientifically documented and assessed.

The goal is to motivate the population to change their diet and exercise habits through increased knowledge on foodstuffs and nutrition and their relationship to diseases. Fat and sugar intake should be reduced, and the intake of fruits and vegetables should be increased. Producers of ready-to-eat foods in the industry and in the catering sector shall create meals with a balanced content of nutrients. When working with diets and eating habits, it should be taken into consideration that some consumers eat too much, there are also consumers that do not eat enough.

Indicators selected under this goal are the following:

Percentage of the population with obesity

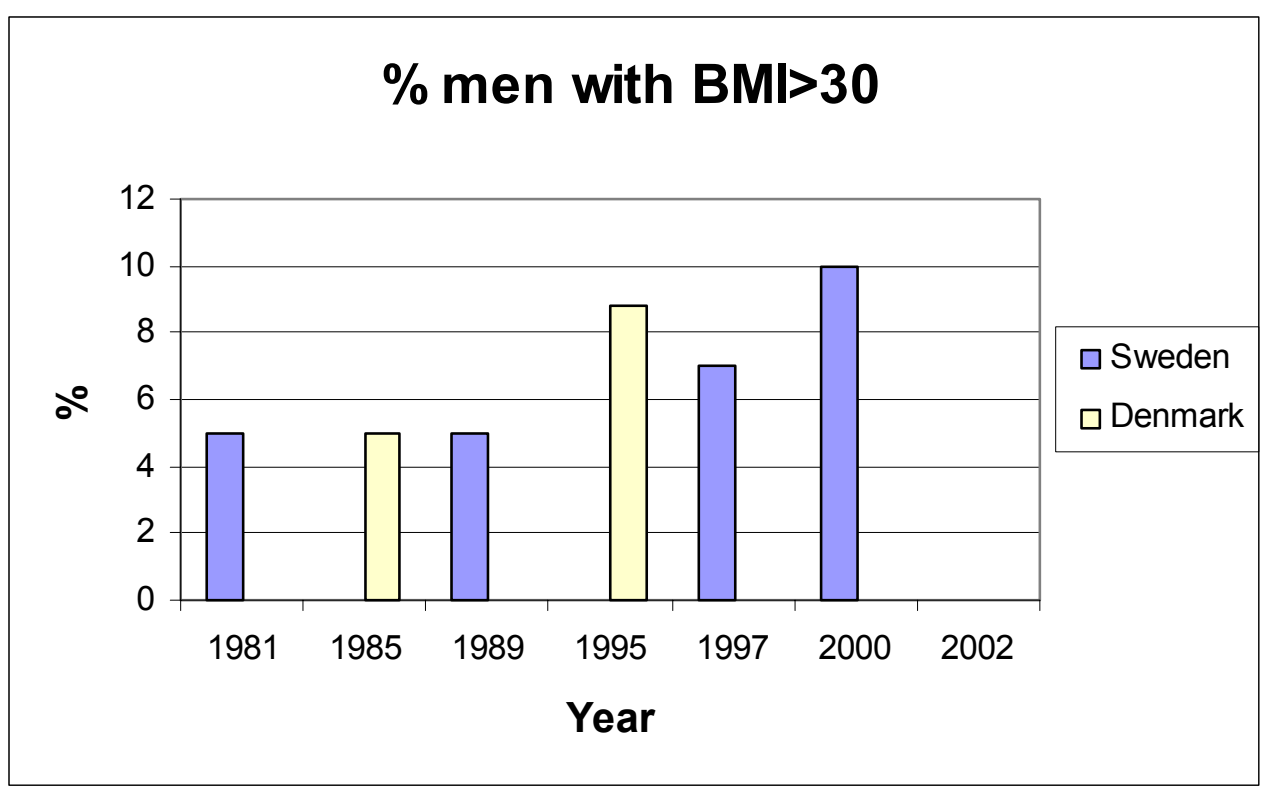




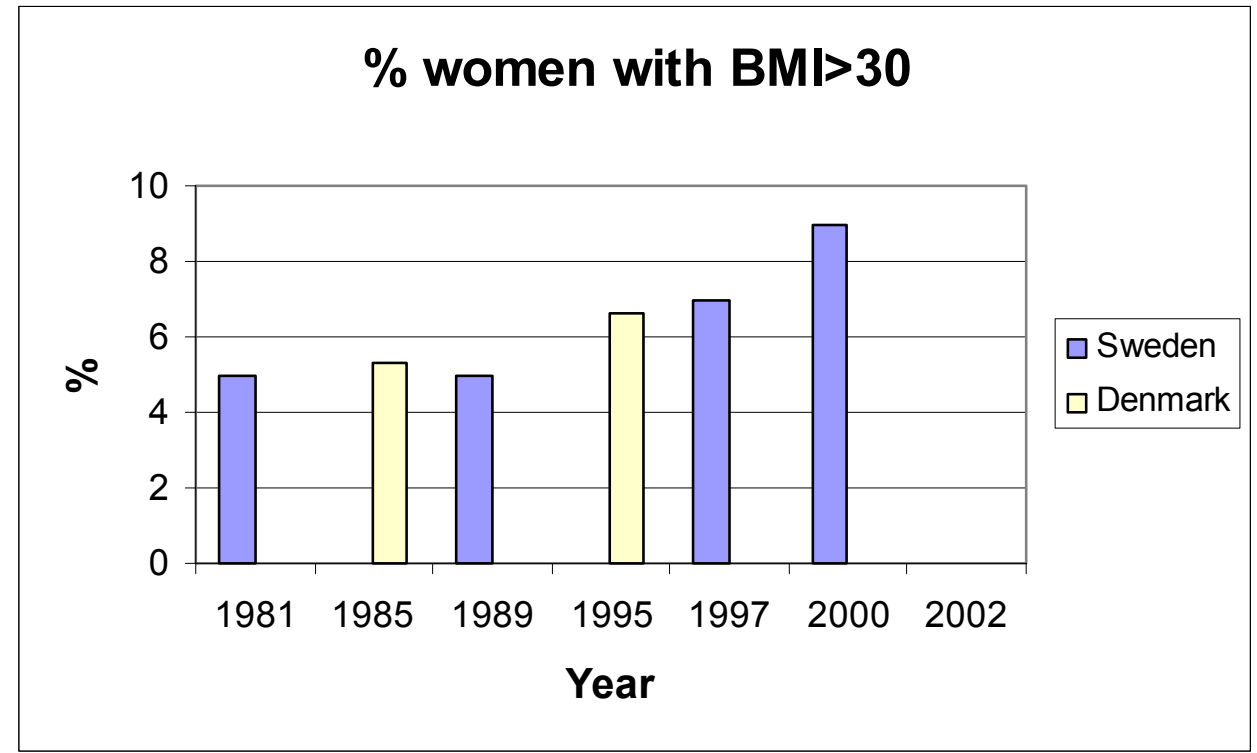

Number of the population with obesity $(\mathrm{BMI}>30)$

\section{Background}

Obesity is an indicator of unbalanced diets, and body mass index (BMI) is a method for measuring obesity. 

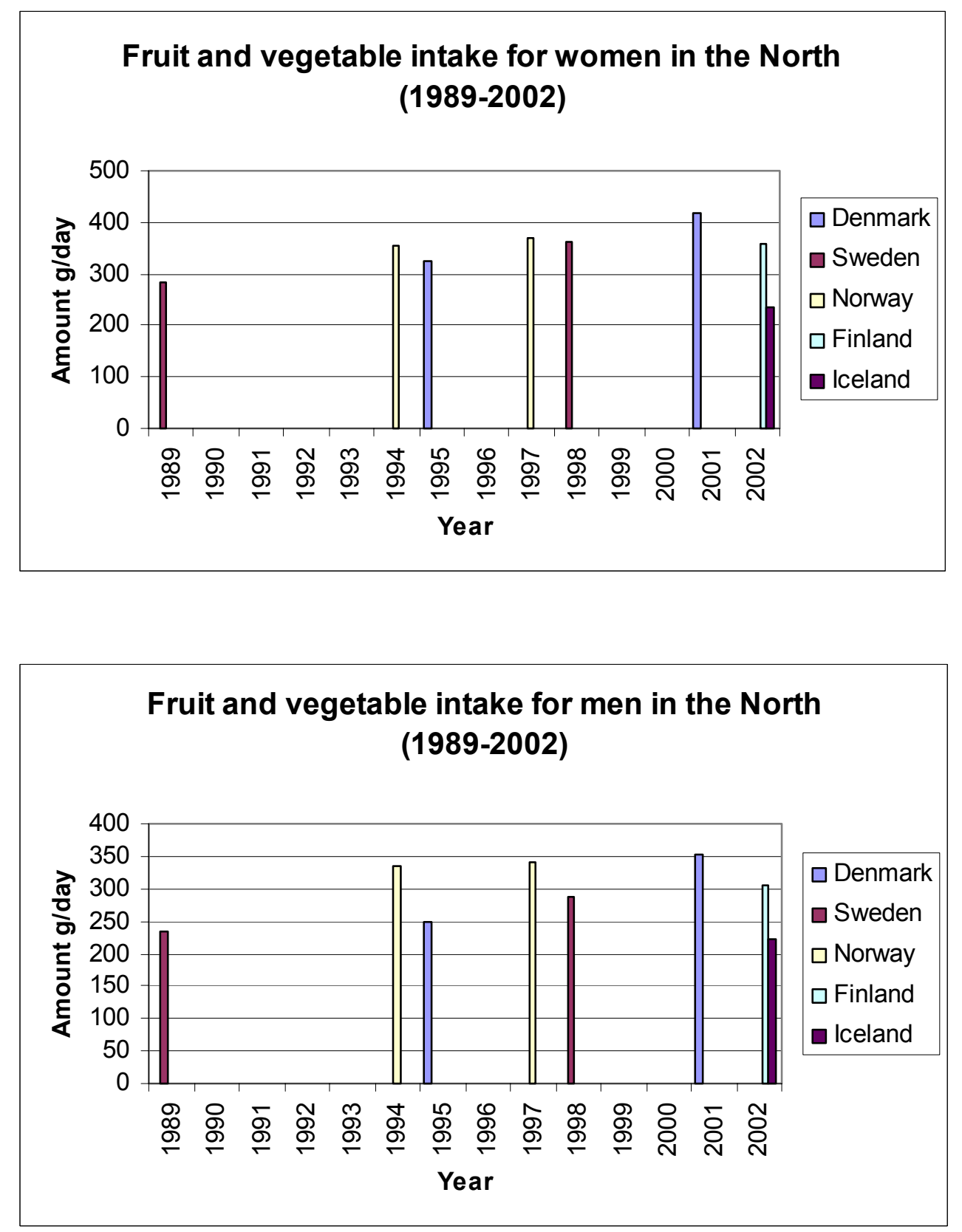

\section{Background}

Nutritionists recommend a high intake of fruit and vegetables, including fruit juice, but excluding potatoes. The indicator gives a signal as to whether the initiatives and recommendations are followed. 


\section{Proposals for future indicators}

\section{Number of schools with free offer of fruit}

\section{Background}

Children should have a possibility to eat fruit independently of costs. Fruit should be an obvious choice for children getting hungry at school. The indicator could follow the initiatives of public authorities as follow-up of the public recommendations.

\section{Number of schools that do not have sales of confectionary and soft drinks}

\section{Background}

Confectionary and soft drinks offer a snack meal but is not a good choice from a nutrional point of view. As it is often the only choice for a snack in schools, the number of schools not offering confectionary and soft drinks would be an indicator on whether local authorities follow-up on the public recommendations for nutrition.

\section{Intake of fruit and vegetables (minus potatoes and fruit juice) in the population,} for children and adults.

\section{Background}

Nutritionists recommend a high intake of fruit and vegetables. The indicator gives a signal as to whether the initiatives and recommendations are followed.

This indicator corresponds to the above-mentioned indicator but fruit juices have been excluded. This future indicator also specifies the intake for children.

\section{Goal: \\ Strengthen traceability and in-house control}

The obligatory in-house control in the industry is a cornerstone in the production of safe and healthy foodstuffs. In-house control has the advantage that the entire production process, from raw materials to the final foods, is controlled. If problems occur, the operator must make adjustments and prevent re-occurrences. The official food control shall use various means to ensure that industry and other food business operators are in compliance with all legislative requirements. The control shall also oversee that inhouse control is well functioning. The effect of official control is strengthened when control results are published. In-house control is also important for the ability to compete, especially on export markets. For imported products, it is of importance that exporters in countries outside the EU and the EEA have a basic understanding and knowledge about the requirements on in-house control.

The Nordic countries should focus on support for in-house control, e.g., by increased traceability and by defining what is understood with a well functioning HACCP 
programme. Furthermore, the Nordic countries should have available the necessary methods of analysis and analytical equipment.

The goal is that all food business operators, including importers elaborate operational HACCP-based in-house control programmes in accordance with the guidelines given in Codex. ${ }^{12}$ Traceability should be strengthened, and so should information on potential risks. The number of foodstuffs not in compliance with valid legislation shall be marginal.

\section{Proposals for future indicators}

Traceability, percentage of food business operators, which have a system for recalling products from the market.

Background

Traceability is a requirement in the European food legislation and has to be implemented in practice. The indicator should illustrate the percentage of industries who fullfill the requirement.

Percentage of companies who have conducted and documented internal revisions of their in-house control programme

Background

The efficiency of in-house control should be revised as needed. The indicator should illustrate whether the food producers use in-house control correctly.

Follow-up by authorities on companies' in-house control, including traceability (control of systems for in-house control)

Background

In-house control is a cornerstone in food safety. The official food control shall see, that in-house control is functioning, and the indicator is a measurement of official follow-up and inspection frequency.

\section{Number of food inspectors with special training (post-degree training) in the} HACCP-systems

\section{Background}

Post-education is an importance prerequisite for all professionals. The indicator is a measure of the updating of know-how of the official food inspectors.

\footnotetext{
${ }^{12}$ Hazard Analysis and Critical Control Point (HACCP) System and Guidelines for its application, Annex to CAC/RCP 1-1969, Rev. 3 (1997).
} 


\section{Number of evaluations of the need of control of import from third countries (areas to be specified)}

\section{Background}

Imports for third countries are from food production outside the control by food inspectors in the Nordic countries or in the European Union.

In order to prioritise the resources needed for the import control of foods, the need for control should be evaluated and priority be given to foods from countries, which have the highest failure rate and therefore present the biggest food safety problem. The indicator monitors such evaluations.

\section{Goal: \\ Strengthen scientific knowledge of food safety}

Knowledge is an important prerequisite for the possibility of obtaining and maintaining safe foodstuffs. The Nordic countries have expertise in food safety, and Nordic scientists participate in many international networks and expert committees. This will result in knowledge being maintained and increase Nordic expertise.

The Nordic countries shall be proactive and prevent problems before they occur. Research in food safety shall be strengthened. Networking is important for building up and exchanging knowledge. Even though good skills are available, there is a continuous need to build up new knowledge, for example, on new foods, processing and environmental contaminants.

Specific risk assessments shall be elaborated internationally, especially in the permanent Committees of the Nordic Council of Ministers for Toxicology, Nutrition and Microbiology, in the panels in the EU, EFSA, and in FAO/WHO expert committees, such as JECFA ${ }^{13}$, JEMPRA ${ }^{14}$, and JMPR ${ }^{15}$. There is an obvious need for continued work in the Nordic co-operation on, for example, inherent toxicants and chemical and microbiological contaminants that are not on the agenda of other international expert fora. It is important also to focus on contamination in the primary production in order to prevent spreading in subsequent links of the chain "from farm to fork".

The Nordic countries shall co-operate and prioritize risk assessments of special areas in international fora, and contribute with, e.g., risk assessment of substances not on the agenda of international organizations.

In addition improved risk assessment models should be developed. This work should take place in co-operation with well-coordinated Nordic research within the food area.

\footnotetext{
${ }^{13}$ Joint FAO/WHO Expert Committee on Food Additives.

${ }^{14}$ Joint FAO/WHO Expert Committee on Microbiological Risk Assessment.

${ }^{15}$ Joint FAO/WHO Expert Committee on Meeting Pesticide Residues.
} 
The goal is research at high level, as a prerequisite of high-level food safety and target oriented risk management. Knowledge is increased by target oriented education and information efforts. The goal is to increase the knowledge about the correlation between diet and health and shall include development of new and better methods of assessment of chemical and microbiological risks, including inherent toxicants. Mapping the contents of chemicals in foodstuffs should be part of the research and include knowledge on protective health promoting substances.

Another goal is to increase food safety by developing better risk assessment models and coordinating research in the Nordic countries.

\section{Proposals for future indicators}

Investment rate (Nordic, national and private) on research in the food safety area, calculated in percentage of BNP

Background

Research should be prioritised in national and international budgets. The indicator should follow the investments in research.

\section{Number of Nordic project (finalised) in the food safety area, including risk profiles}

Background

The Nordic co-operation in the food safety area focuses on risks not dealt with elsewhere internationally. The indicator should measure the results coming from the cooperation.

Number of scientific publications, including Nordic reports etc. sent to JECFA, EFSA, Codex Alimentarius, WHO and OECD

\section{Background}

The Nordic co-operation in the food safety area focus on risks not dealt with elsewhere and often consists of contributions to the international food safety discussions and assessments. The indicator should measure the results used in the international cooperation.

Goal:

\section{Strengthen consumer knowledge}

Foodstuffs are essential for maintaining life, and it is of major importance that everyone has basic knowledge about food, food safety, and food quality.

At the same time, it is of importance that those who should receive information have basic knowledge on which to build. A high level of knowledge among the population is of major importance for a high level of food safety. 
In addition to a basic level of knowledge, it is important to enable consumers to make qualified choices of food products. Availability of relevant information is important when consumers make their choices, including putting together foods while keeping food safety in mind. Labelling of foodstuffs and information about, foodstuffs shall take place in such a way that the consumer has sufficient basis for the evaluation of the foodstuffs with regard to nutrition, quality, origin, and ethics in the preparation.

The Nordic countries should aim at ensuring honest risk communication and for correct information in all circumstances, including cookbooks, television programs, and articles in the media. The authorities and the industry should increase their information efforts and supply sufficient information, e.g. over the Internet.

The Nordic countries will ensure that the basic education in schools includes all aspects relevant for food safety.

The goal is to work for increased education in schools covering all aspects of importance for food safety and with regard to sustainable development as part of the basic knowledge among the population. Basic knowledge communicated in ordinary schools will enable target directed information on new knowledge, advice, and, if necessary, security measures.

Another goal is for consumers to have the availability of information and education to be able to maintain and increase their knowledge on factors of importance for food safety. All stakeholders - authorities, food business operators and consumer organizations - have the responsibility of relating information to consumers. 


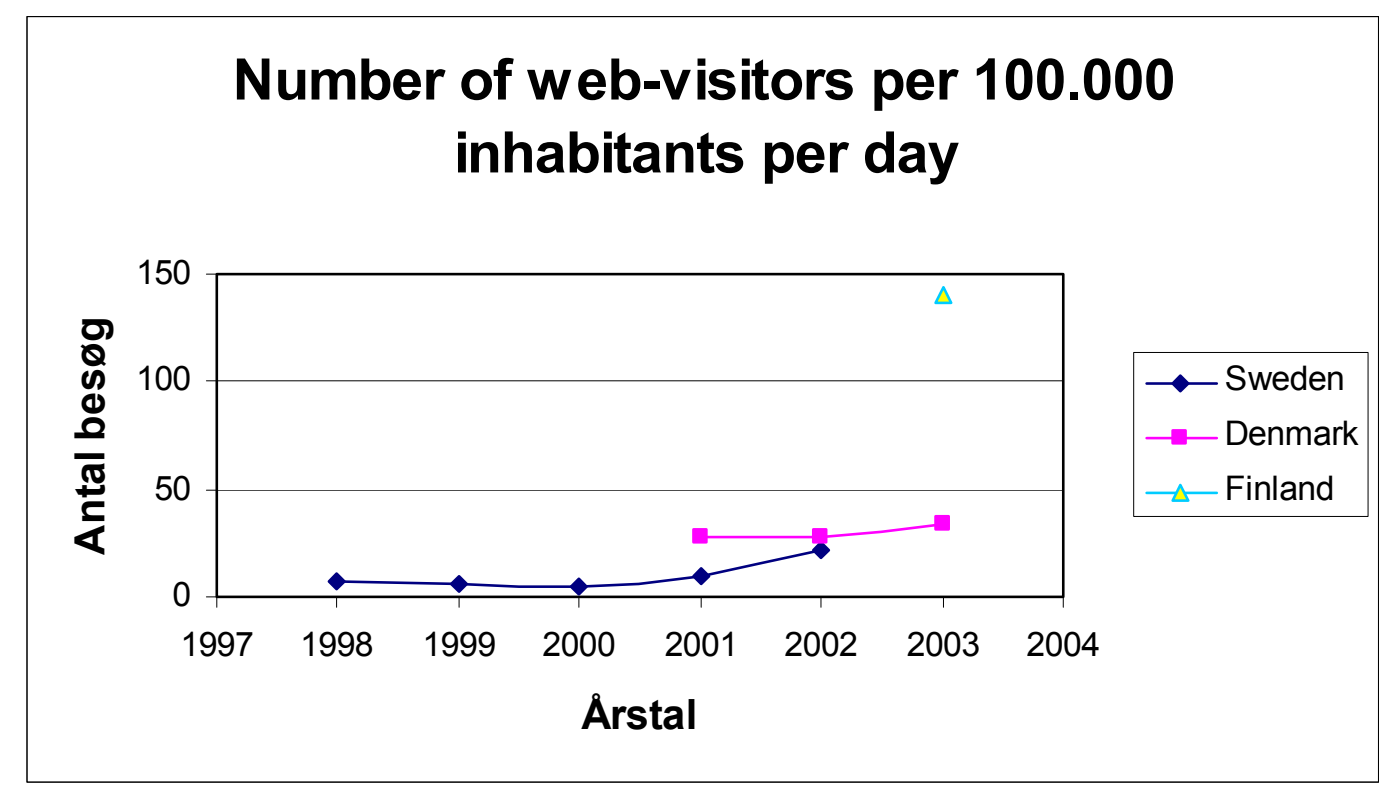

Number of visits on the websites of the food safety authorities

Background

Education of consumers should start at school and continue afterwards. Much information is available on the Internet. Visits to websites would be a measure of the efficacy of the type of information channel.

\section{Proposal for a future indicator}

Education hours in schools addressing food safety issues.

Background

Education of consumers should start at school. This would create a platform for understanding of information on new issues of importance for food safety. Hours of education at school would be an indicator of the potential knowledge on food safety. 


\section{Discussion and conclusions}

Food safety is of importance for many reasons, especially for consumer's safety and health. Sustainable development in food safety is important for the next generation and life on earth. Food safety and food security is interconnected with environment, transports and many other aspects.

Many of the risks associated with food safety can be prevented if attention is paid to problems in due time and the same would be the case in sustainable development of food safety. Food safety and sustainable development should be considered in all links of the food chain - in the selection and production of raw materials, in processing -both in the primary production and in the industrial production, in the use of chemicals like flavours, food additives and chemicals in food packaging, in composition of the diet etc. Control of food production is the responsibility of the primary producers, other food business operators including the industry and the importers and the official food control. Consumers are responsible for their choice and composition of the diet. In order to be able to take responsibility, education and information is essential.

A number of activities have taken place to ensure food safety, both nationally and internationally. The work on sustainable development on food safety is a useful way towards specified goals. The focus tasks can and will change over the years, but to optimize the efforts, it is useful to formulate the goals.

Indicators are found to be a valid tool to be used in relation to future goals or sub-goals. When work is initiated towards a specific goal (or sub-goal), selection of indicators should be discussed and decided on. Indicators could be a useful tool, both in relation to a national strategy in a specific area and in joint, international work towards selected goals. In such discussions, timeframes regarding the selected data should be agreed and criteria on when this selection should be finalized. Data collection is needed in order to document the development. It is also important to agree when data collection should be discontinued, as resources in most countries normally are limited.

Conclusions from the project are:

- Sustainable development in food safety is important for humanity

- Focus on the crucial goals would optimize the efforts made

- Selected indicators provide a tool for measurements of the result of the initiatives

- Selection of indicators provides a measure for correction or change of activities 
Obtain your Nord and TemaNord reports from:

\author{
BELGIUM \& LUXEMBOURG \\ Jean de Lannoy \\ Avenue du Roi, 202, 1190 Brussels \\ Tel +32 (0)25385169 \\ Fax +32 (0)2538 0841 \\ jean.de.lannoy@euronet.be
}

\section{CANADA}

Renouf Publishing Company Ltd

5369 Canotek Road, Ottawa,

Ontario K1J 9J3

Tel + 1 (613) 7452665

$\mathrm{Fax}+1$ (613) 7457660

order.dept@renoufbooks.com

www.renoufbooks.com

\section{CHINA}

CNPIEC

Europe Division 16 Gongti East Road,

P.O. Box 88, Beijing

Tel +86105066 688-8

Fax +86 105063101

\section{DENMARK}

Svensk-Norsk Bogimport A/S

Esplanaden 8 B, 1263 København K

Tel +4533142666 Fax +4533143588

snb@bog.dk

www.snbog.dk

\section{ESTONIA}

Astro Raamatud AS

Pärnu mnt 142, 11317 Tallinn

Tel +372 6548485 Fax +3726548475

book@astro.ee

\section{FAROE ISLANDS}

H.N. Jacobsens Bókahandil

Postboks 55, 110 Tórshavn

Tel +298 311036 Fax +2983178 73

hnj@hnj.fo

www.hnj.fo

\section{FINLAND}

Akademiska Bokhandeln

PB 128, Centralgatan 1,

00101 Helsingfors

Tel +358 912141

akatilaus@akateeminen.com

www.akateeminen.com

\section{FRANCE}

Librairie LAVOISIER

14 , rue de Provigny,

94236 Cachan Cedex

Tel +33 (1) 47406700

Fax +33 (1) 47406702

group@lavoisier.fr

www.lavoisier.fr

\section{GERMANY}

UNO-Verlag GmbH

Am Hofgarten 10, 53113 Bonn

Tel +49 (0)228949020

$\mathrm{Fax}+49$ (0)228 9490222

info@uno-verlag.de

www.uno-verlag.de

\section{HUNGARY}

Euro Info Service

PO Box 1039, 1245 Budapest

Tel +36 (1) 3292487

Fax +36 (1) 3492053

euroinfo@euroinfo.hu

\section{ICELAND}

Mál og Menning

Laugavegi 18, 101 Reykjavik

Tel +354 (9)5152500

Fax +354 (9)515 2505

verslun@mm.is

\section{LATVIA}

Jana Rozes Gramàtnica

Kr. Barona iela 5, 1011 Riga

$\mathrm{Tel}+371(0) 2284288$

Fax +3717370922

\section{LITHUANIA}

Penki Kontinentai

A. Stulginskio 5, 2001 Vilnius

Tel +370 (5) 2664540

Fax +370 (5) 2664565

books@5ci.lt

www.books.lt

\section{NORWAY}

Akademika A/S

Postboks 84 Blindern, 0314 Oslo

Tel +4722853030 Fax +4722 853080

bloken@sio.uio.no

www.akademika.no

\section{ROMANIA}

Euromedia s.r.I.

Str Dionisie Lupu nr 65, 70184 Bucuresti

Tel + 4016140664

$\mathrm{Fax}+4013129646$

\section{SWEDEN}

Fritzes

Kundservice, 10647 Stockholm

Tel +46 (0)8 6909190

$\mathrm{Fax}+46(0) 86909191$

order.fritzes@nj.se

www.fritzes.se
THE NETHERLANDS

De Lindeboom Internationale Publicaties

M.A. de Ruyterstraat $20 \mathrm{~A}$,

NL-7482 BZ Haaksbergen

Tel +31 (0)53 5740004,

Fax +31 (0)535729296

books@delindeboom.com

www.delindeboom.com

\section{UNITED KINGDOM}

The Stationery Office

P.O. Box 276, London SW8 5DT

Tel +448706005522

Fax +44 8706005533

customer.services@tso.co.uk www.tso.co.uk/bookshop

USA

Bernan

4611-F Assembly Drive,

Lanham MD 20706-4391

Tel +1 (301) 4597666

Fax +1 (301) 4590056

query@bernan.com

www.bernan.com

\section{ÅLAND}

Lisco bok- och pappershandel

Skarpansvägen 25, Box 8 ,

22101 Mariehamn

Tel +358 (0)1817 177

Fax +358 (0)18 19771

info@lisco.fi 